\title{
The Antifungal Activity of Naphthoquinones: An Integrative Review
}

\author{
DÉBORA O. FUTURO ${ }^{1}$, PATRICIA G. FERREIRA ${ }^{2}$, CAROLINE D. NICOLETTI ${ }^{2}$, LUANA P. BORBA- \\ SANTOS ${ }^{4}$, FERNANDO C. DA SILVA ${ }^{3}$, SONIA ROZENTAL ${ }^{4}$ and VITOR FRANCISCO FERREIRA ${ }^{1}$ \\ ${ }^{1}$ Universidade Federal Fluminense, Departamento de Tecnologia Farmacêutica, Faculdade de \\ Farmácia, Rua Mario Viana, 523, Santa Rosa, 24241-002 Niterói, RJ, Brazil \\ ${ }^{2}$ Universidade Federal Fluminense, Faculdade de Farmácia, PPGCAPS, Rua \\ Mario Viana, 523, Santa Rosa, 24241-002 Niterói, RJ, Brazil \\ ${ }^{3}$ Universidade Federal Fluminense, Instituto de Química, Departamento de Química Orgânica, \\ Outeiro de São João Batista, s/n, Centro, 24020-141 Niterói, RJ, Brazil \\ ${ }^{4}$ Universidade Federal do Rio de Janeiro, Instituto de Biofísica Carlos Chagas Filho, Centro de Ciências \\ da Saúde, Bloco G, G044, Cidade Universitária, 21941-901 Rio de Janeiro, RJ, Brazil
}

Manuscript received on October 11, 2017; accepted for publication on December 8, 2017

\begin{abstract}
Naphthoquinones are the most commonly occurring type of quinones in nature. They are a diverse family of secondary metabolites that occur naturally in plants, lichens and various microorganisms. This subgroup is constantly being expanded through the discovery of new natural products and by the synthesis of new compounds via innovative techniques. Interest in quinones and the search for new biological activities within the members of this class have intensified in recent years, as evidenced by the evaluation of the potential antimicrobial activities of quinones. Among fungi of medical interest, yeasts of the genus Candida are of extreme importance due to their high frequency of colonization and infection in humans. The objective of this review is to describe the development of naphthoquinones as antifungals for the treatment of Candida species and to note the most promising compounds. By using certain criteria for selection of publications, 68 reports involving both synthetic and natural naphthoquinones are discussed. The activities of a large number of substances were evaluated against Candida albicans as well as against 7 other species of the genus Candida. The results discussed in this review allowed the identification of 30 naphthoquinones with higher antifungal activities than those of the currently used drugs.
\end{abstract}

Key words: Quinones, xanthenes, lapachol, lawsone, Candida spp, disc diffusion method.

\section{INTRODUCTION}

As life evolved, several chemical and biochemical routes developed that allowed the diversification and

Correspondence to: Vitor Francisco Ferreira

E-mail: vitorferreira@id.uff.br

* Contribution to the centenary of the Brazilian Academy of Sciences. specialization of the first organisms. Consequently, this increased the degree of sophistication in terms of organization, structure and function and led species to specialize in terms of the production of molecules with specific functions. Later, evolutionary paths led to new chemical reactions that produced molecules capable of replicating 
and giving origin to other molecules. At the same time, species began to produce small functional molecules that modulate several evolutionary biochemical processes to allow them to adapt their morphologies, physiologies, habits, water and nutrient uptake, animal-plant interactions and animal-animal interactions to their habitat (environment). These features were used by Gottlieb (1992), an outstanding Brazilian scientist who studied the phylogeny and chemosystematics of several plant families and the natural products produced by those families. He established new taxonomies and elucidated phylogenetic tendencies using secondary metabolites that were fundamental for understanding the relationship of plants with their respective ecosystems. These aspects of evolution led to the development of natural products that are of great importance to humanity. The vast biodiversity of rainforest regions holds many potential substances that can be used as drugs to treat human diseases such as cancer (Ferreira et al. 2008, Izumi et al. 2011). Indeed, in some developing countries almost $80 \%$ of the population depends on ethnobotanical medicines (Pinto and Castro, 2009).

Quinones are small, six-membered $\alpha, \beta$ dienonic rings with well-defined functional activities that occur in plants, fungi, lichens, bacteria, algae, viruses, insects and higher organisms. The complexity of these compounds evolved with the species themselves (Thompson 1997). For instance, this is a class of secondary metabolites in the Bignoniaceae family (Cipriani et al. 2012), and the naphthoquinone lapachol, which was initially isolated from Handroanthus impetiginosus and has significant anticancer properties, is the most commonly occurring quinone in this family.

Quinones are classified according to their aromatic carbon skeleton. The most common are the benzoquinones, naphthoquinones, anthraquinones and phenanthrenequinones (Figure 1). In organisms, these compounds are related to chemical defenses and have specific biological functions in electron transfer in various oxidative processes in aerobic metabolism, such as photosynthesis, oxidative phosphorylation and other electron transfer reactions (Castro et al. 2008, Silva Júnior et al. 2008, Coates et al. 2013). Some of these quinones are involved in multiple metabolic processes in animals, microorganisms and plants. Among these compounds, benzoquinones stand out; these compounds include coenzyme Q (ubiquinones, 1) and the vitamin $\mathrm{K}$ family (Figure 1), which participates in electron transport during cellular respiration and blood coagulation (Mahler and Lordes 1971). Plastoquinones (2, Figure 1) are found in the chloroplasts of plants and algae and are involved in the transport of electrons during photosynthesis (Goodwin and Mercer 1972). Vitamins K1 (3), K2 (4) and K3 (5) (Figure 1) are synthesized by intestinal bacteria, but they are also present in several plants consumed as food and are essential for the formation of prothrombin, a chemical necessary for blood clotting (Dowd et al. 1995). The vitamin $\mathrm{K}$ family is large, and most of the members are commercially available as therapeutic treatments. From an ecological point of view, quinones are considered protective not only for plants but also for insects. The best-known example of this is the strategy adopted by some beetles to combat predators wherein they emit a spray consisting of vaporized benzoquinones and oxygen.

\section{MECHANISMS OF BIOLOGICAL ACTION OF QUINONES}

Quinones can be cytotoxic through several mechanisms of action, including redox cycles, arylation of the thiol groups of proteins, intercalation, induction of breaks in the DNA chain, generation of free radicals and other reactive oxygen species (ROS) and bioreductive alkylation via the formation of quinone methide. However, it is still unclear whether one mechanism of action is 


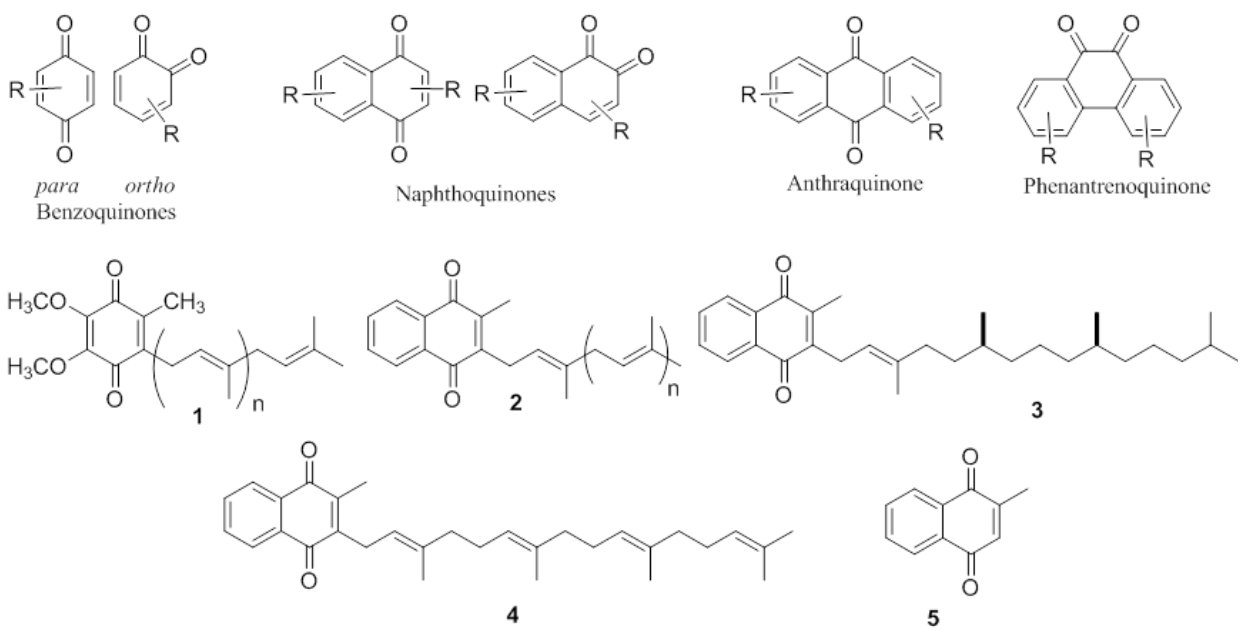

Figure 1 - General structures and examples of quinones with important metabolic functions.

more prevalent than the others. Synthetic analogs can be modulated to act selectively via one of several mechanisms of action, especially when the structures of the synthesized molecules are similar to the natural or endogenous quinones of the organisms. In these cases, it is reasonable that these analogs can act in the same way and interfere in the same cellular biochemical processes. For example, quinones are involved in the intracellular transport of electrons, and it is generally accepted that exogenous quinones can transfer electrons in biological processes; this is an important cyclic property as oxidation is followed by reduction and vice-versa (Bendz 1948, Tanaka et al. 1975, Binkley et al. 1939). As electron transport via quinones is not inherent to the biochemical machinery, this process can initiate a cascade of unstable free radicals that react with other molecules generating free radicals that react rapidly with oxygen to generate reactive oxygen species (ROS), such as superoxide, hydroxyl radical, and hydrogen peroxide. These cascades of biochemical processes are catalyzed by NADPH-cytochrome P450 reductase and other flavoproteins, which may damage cellular components, such as DNA, lipids and proteins, causing direct damage to the cell (Castro et al. 2013, Kumagai et al. 2012).
Another possible mechanism for the cellular cytotoxicity of some specific quinones is the in situ generation of ortho- or para-quinone methides (QMs). QMs are very reactive intermediates that can be used in various chemical reactions (Ferreira et al. 2009), and they are generated in various biological processes, such as tree lignification, enzyme inhibition, phosphodiester reactions, alkylation and DNA cross-linking (Cao et al. 2014). This mechanism of action is quite common in quinones and has been used in nature as well as in prototypes and drugs in medicinal chemistry (Toteva and Richard 2011, Phillips et al. 1999, Wellington 2015, Lin et al. 1972, 1973, 1975). A classic example is the drug mitomycin $\mathrm{C}$, which is a natural product isolated from Streptomyces coeruleorubidus and is commercially available as a therapeutic drug for use in humans against leukemia (Acton et al. 1979), several types of cancers (Kurylowicz 1981) and Trypanosoma rhodesiense (Wilhanson and Scott-Finningan 1981). Its mechanism of action is via its transformation into an intermediate capable of bioalkylating the DNA of tumor cells; however, other modes of action, such as the redox cycle and the inhibition of rRNA, can also contribute to the biological action of the drug (Paz et al. 2012). Troglitazone is an antidiabetic drug, and 
its mechanism of action involves activation by cytochrome P450 leading to a QM. This drug was withdrawn from the market in March 2000 because of its hepatotoxicity possibly via the formation of covalent adducts with liver proteins that are deleterious to the liver (Kassahun et al. 2001). On the other hand, tamoxifen acts as a selective estrogen receptor modulator in breast tissue through its active metabolite hydroxitoxifene. This drug generates a QM through a P450-catalyzed twostep oxidation (Fan and Bolton 2001). However, the involvement of a quinone-methide intermediate generated in the in vivo from tamoxifen has never been effectively demonstrated.

Recently, Silva et al. (2016) proposed that the mechanism of action of pterocarpanquinone (LQB118), which is active against the promastigotes of Leishmania amazonensis, passes through a QM. This observation was made indirectly by electrochemical and spectroscopic studies in aprotic and protic media with and without oxygen and through its interactions with DNA under different conditions (Silva et al. 2016). New substances and new strategies for exploring these endogenous cellular mechanisms of QM action still need to be developed.

Another mechanism of action related to the cytotoxicity of naphthoquinones is their action on the enzymes topoisomerase I and II (Piyta et al. 1998). There are many published studies indicating that quinones, more specifically naphthoquinones, inhibit either one or both of these enzymes (Cunha et al. 2006, Coelho-Cerqueira et al. 2014, Karkare et al. 2013). Beta-lapachone (6) is the best-known quinone believed to inhibit topoisomerases I (Chiang et al. 1993), which is believed to inhibit topoisomerases I (Boothman et al. 1989, Frydman et al. 1997) and II (Krishnan and Bostow 2000). Direct incubation of this substance with topoisomerase I prior to the addition of DNA dramatically increases the inhibitory effect, suggesting $\beta$-lapachone directly interacts with topoisomerase I. Another example that indicates the breadth of potential functions of naphthoquinones is TU100. This naphthoquinone is able to efficiently inhibit topoisomerase I and II enzymes, which act on the cell cycle, acting on one or both strands of DNA. Because of this dual inhibitor effect with a unique mechanism of action, this quinone has great potential to become a chemotherapeutic agent (Kennedy et al. 2011). Estévez-Braun synthesized and evaluated compounds with moieties conjugated between a naphthoquinone and coumarin as inhibitors of topoisomerase II. All compounds tested were active at submicromolar concentrations (Hueso-Falcóna et al. 2017). It is important to note that these nuclear enzymes are critical to the normal function and integrity of DNA by repairing damage by binding to one or two helices and are therefore important targets for the design of new naphthoquinones. The substances that act on topoisomerases can be divided into two classes: 1) stabilizers of the topoisomerase-DNA complex and 2) catalytic topoisomerase inhibitors (Bassi and Palitti 2000). Inhibitors of topoisomerases I and II by mechanism 1 are more numerous.

Considering the structural diversity of naphthoquinones, the similarities of the biochemistry of endogenous naphthoquinones and the diversity of their mechanisms of action, it is not surprising that these substances may have the capacity to treat and cure human cellular degenerative diseases or diseases caused by viruses or pathogenic microorganisms. These naphthoquinones can be synthesized or isolated from natural products in the form of extracts, teas, powders, oils, roots, etc. Many of these extracts are widely used in folk medicine and are recognized in traditional medical practices. In addition, the natural products produced by these plants, fungi, viruses and bacteria have been a source of inspiration for structural modifications by rational synthetic transformations for developing new and more active products for the treatment of some of the 
most important diseases affecting humanity (Coseri 2009, Gordaliza 2007, Soejarto and Farnsworth 1989, Raskin et al. 2002, Melo et al. 2011). For example, approximately $74 \%$ of the drugs used in cancer chemotherapeutics are natural products, their derivatives or their synthetic analogs (Butler 2008, Tan et al. 2006).

It is important to note that the selection of these two subjects was because synthetic naphthoquinones have been widely screened against many biological targets (Asche 2005, Skibo et al. 2001, Gafner et al. 1996), such as the HIV1 virus reverse transcriptase enzyme (Stagliano et al. 2006), and they have been explored for use as anticancer (Liu et al. 2004, Lu et al. 2013, Murakami et al. 2010, Montenegro et al. 2010), leischmanicidal (Kayser et al. 2000, Jernigan et al. 1996, Teixeira et al. 2001), antimalarial (Hooker and Richardson 1948), toxoplasmosis (Ferreira et al. 2002) and trypanocidal (Diogo et al. 2013, Pinto et al. 2000, Pinto and Castro 2009, Salas et al. 2011) agents.

Naphthoquinones are the most commonly occurring type of quinones. They are a diverse family of secondary metabolites that occur naturally in plants, lichens and various microorganisms (Morton 1965, Patai 1974, Patai and Rappoport 1988, Thomson 1997). This subgroup is constantly being expanded through the discovery of new natural products and new compounds that are synthesized via innovative methods. The interest in quinones and the search for quinones with new biological activities has intensified in recent years due to the pharmacological relevance of three important natural naphthoquinones: $\beta$-lapachone (6), lapachol (7) and lawsone (8) (Figure 2)(Silva and Ferreira 2016).

CANDIDIASIS: A WORLDWIDE GLOBAL HEALTH PROBLEM

Fungi are an important group of pathogens even though fungal infections are neglected by the public health and global health communities (Nature Microbiology 2017). Over 300 million people are acutely or chronically infected by fungi, leading to death, long term illness and reduced work capacity in more than 140 countries around the world. It is estimated that 1.6 million deaths occur annually due to fungal infections (LIFE 2017a). Although there are approximately 2 million fungal species, approximately 600 are potentially pathogenic to humans, and of those, only 30 species are commonly isolated from human patients (LIFE 2017b).

Candida spp. are the most common cause of fungal infections in humans. They are a natural member of the human microbiota and usual live in harmony with humans in the gut and on mucosal surfaces, but when the natural balance is disrupted, infections can occur. In these cases, Candida spp. infections can range from superficial to systemic and disseminated forms; however, systemic and disseminated infections occur mainly in immunocompromised patients (Gow and Hube 2012). Candida spp. is the fungal species responsible for the fourth most hospital-acquired bloodstream infections (Wisplinghoff et al. 2004), and invasive candidiasis has a high mortality rate ranging from 45 to $75 \%$ (Brown et al. 2012). Thus, Candida spp. are classified by the U.S. Centers for Disease Control and Prevention (CDC) as a serious threat to human health due to its increasing resistance to antifungal drugs (CDC 2017a).

Although Candida albicans is still the most prevalent fungus, there has been a shift in distribution of species. This mean that of the invasive candidiasis species, the non-Candida albicans species are now more prevalent than they were a few years ago, and several of these species display high rates of antifungal resistance (Benedict et al. 2017). Candida glabrata, Candida parapsilosis, Candida tropicalis and Candida krusei are the most common species outside of non-Candida albicans, and their prevalences vary between different geographic regions. C. glabrata 


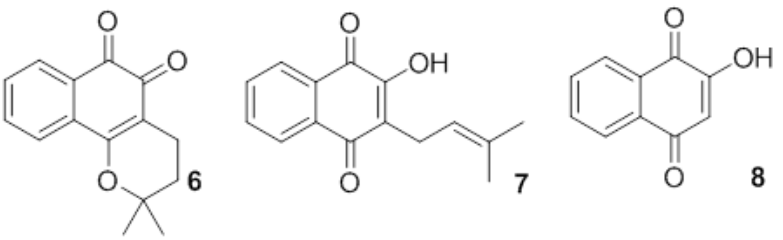

Figure 2 - Structures of three important natural naphthoquinones and some related drugs.

is the second most common fungal species in the USA, UK, northern Europe and Australia; $C$. parapsilosis is ranked second in southern Europe, and $C$. tropicalis is second in India. C. tropicalis and $C$. parapsilosis are also the second and third most prevalent species in Brazil. An important characteristic of C. glabrata and C. krusei is that these species are intrinsically less susceptible to fluconazole than other Candida spp. (Colombo et al. 2017).

Three major classes of antifungal agents are available to treat invasive fungal infections, namely, polyenes, echinocandins and triazoles, and the main fungal targets are the fungal plasma membrane and the cell wall. An example of a polyene-type antifungal agent is amphotericin B, which destabilizes membranes due its binding to ergosterol allowing it to act as a sponge. Echinocandins, such as caspofungin, micafungin and anidalafungin, block cell wall biosynthesis by blocking the catalytic subunit of the $\beta-1,3-$ glucan synthase. While triazoles inhibit the biosynthesis of ergosterol by blocking lanosterol at the $14 \alpha$-demethylation step. Triazoles are the most used antifungal in medical practices, and fluconazole is the most common triazole-derived antifungal in clinical settings (Sanglard 2016).

The main antifungal used to treat invasive infections due to Candida is fluconazole (intravenous or oral). In some cases, echinocandins can be used during initial therapies with a posterior transition to fluconazole. Amphotericin B (lipid formulation administered intravenously) is the only alternative in patients with azole- and echinocandin- resistant Candida infections (Pappas et al. 2016). In addition to fluconazole, topical formulations of clotrimazole, miconazole, both are imidazole antifungals) or nystatin, a polyene antifungal (CDC 2017b) could be used to treat superficial Candida spp. infections.

However, over the years, the use of antifungal agents for the treatment of fungal diseases has led to a new problem: antifungal resistance to fungi. The main mechanisms of antifungal resistance identified in Candida spp. are decreases in the effective antifungal concentration and antifungal target alteration. In the first case, the intracellular concentrations of antifungals can be decreased by active efflux mediated by efflux transport systems (ATP-binding cassette (ABC) transporter or transporters of the major facilitator superfamily (MFS)). The antifungal target can also be overexpressed causing the effective drug concentration to decrease. In addition, the antifungal can be sequestered in extracellular compartments formed by Candida biofilms. In the second case, the enzyme that the antifungal binds can change due to mutations (Sanglard 2016).

The increase in the incidences of fungal infections, the high rates of morbidity and mortality, the limitations in antifungal options and the occurrence of antifungal resistance highlight the importance of the development of new antifungal strategies (Scorzoni et al. 2017). However, both fungi and their human hosts are eukaryotic, thus their inherent similarities make the search for new antifungal molecules or antifungal targets much more challenging.

Attempts to elucidate the activity of small natural and synthetic molecules against infections caused by microorganisms have been frequently conducted for more than one hundred years to meet the health, social, environmental and economic needs of mankind. Many researchers have devoted a substantial amount of their time to understanding the biochemical functions of microorganisms 
and their relationships with the human species. Today, diseases caused by microorganisms, such as those caused by fungi, remain neglected despite the substantial amount of effort invested by the scientific community to understand these diseases. To identify new molecules with high degrees of specificity and lower incidences of side effects, much more research needs to be done to understand the mechanisms controlling the biochemistry of these diseases and their relationship with their host. On the other hand, due to economic concerns, profitable diseases remain the focus of the pharmaceutical industry. In summary, new drugs are needed to meet the demands for both new and old diseases that are still not fully understood, and as we will discuss in this review, naphthoquinones belong to a class of natural and synthetic molecules with great potential for antifungal activity.

\section{MATERIALS AND METHODS}

This study is an integrative review of the scientific literature involving antifungal naphthoquinones. The assembly of this review was conducted via the following steps: formulation of the objective and the research scope, determination of the inclusion and exclusion criteria, data analysis (including ordering, coding, categorization and summarizing), data interpretation and reporting the findings. (Whittemore and Knafl 2005)

The selection of publications was guided by two questions: (1) what is the scientific evidence for the antifungal activity of the naphthoquinone against Candida spp.; and (2) which naphthoquinones presented in the literature show the most promising antifungal activity against Candida spp. The survey was conducted using the Scopus ${ }^{\circledR}$ and SciFinder ${ }^{\circledR}$ electronic databases with "naphthoquinone" and "antifungal" as the controlled descriptors. The data were collected from June to July 2017. To be included a paper had to meet the following criteria: they had to be scientific papers dealing with studies on the antifungal activity of naphthoquinones, they had to be reporting research using fungi related to human or animal health, they had to be available in English, and they had to have been published between 2000 and June 2017. Editorials and reviews were excluded.

Initially, all the publications obtained in the literature search $(\mathrm{n}=451)$ were examined for relevance and the inclusion criteria. Those that did not meet the criteria specified above or duplicates were excluded. The first selection stage resulted in a sample of 79 publications.

The selected publications were fully and systematically analyzed to classify the antifungal activity and origin (synthetic or natural products) of the quinones. We also investigated the methodology used in the antifungal evaluation and which species were tested.

From this selection, it was observed that $86 \%$ of the publications $(n=68)$ evaluated the antifungal activity of the naphthoquinones against several Candida spp. These publications were selected for a more detailed study of the method used to test the antifungal activity to allow a more precise and efficient selection of the antifungal activity of the most promising prototype compounds. In this regard, two other inclusion criteria were added: (1) the antifungal activity as indicated by the minimum inhibitory concentration (MIC) had to be determined by the microdilution method and (2) the activity of the quinones had to be compared to the activities of standard antifungal drugs used in medical clinics.

The terminology used to place results into interpretive categories was established as the following: level 3 for naphthoquinones with MICs up to twice the values of the standard antifungal drugs; level 2 for naphthoquinones with MICs equal to those of the standard antifungal drugs, and level 1 for naphthoquinones with MICs lower than those of the standard antifungal drugs. 


\section{RESULTS}

Approximately $57 \%$ of the relevant papers (68) for this review were published between 2012 and 2017. The authors are from 30 countries, with India (29.4\%), Ukraine (19\%), Turkey (16\%) and Brazil $(8.8 \%)$ being the most represented countries. A significant number of publications (23.5\%) involved the participation of diverse research groups from different universities and research centers and from different countries, highlighting the importance of national and international partnerships.

Most of the publications discussed in this review reported the activities of synthetic naphthoquinones (57); only 11 publications evaluated naturally occurring naphthoquinones. These publications revealed that 691 naphthoquinones were screened for antifungal activity against Candida spp. It is worth noting that $98.5 \%$ of the publications involved synthetic 1,4-naphthoquinones derivatives.

Methods for studying antifungal effects in vitro and in vivo have differed considerably over time and among investigators, and the logic behind these interpretive categories is worth discussing. The antimicrobial activities of naphthoquinones in the publications evaluated in this review were determined using the disc diffusion method (DM) and/or by the microdilution method (MD). Most publications expressed the results of antifungal activity in MIC (57); a smaller fraction expressed the activity in terms of the diameter of the zone of inhibition (11). It should be noted that some of these reports expressed antifungal activities by both methods. Only 32 publications directly compared the efficiencies of their quinones to the those of standard antifungal drugs. Eight standard antifungal drugs were used: amphotericin B, nystatin, ketoconazole, clotrimazole, fluconazole, griseofulvin, itraconazole and miconazole. Publications that used reference compounds that are not commonly used clinically against Candida spp. were discarded.
The following Candida spp. were used in these studies: C. albicans, C. dubliniensis, C. glabrata, C. kefir, C. krusei, C. parapsilosis, C. tenuis, and C. tropicalis. The specimens were obtained from Culture Collection of microorganisms as well as from species isolated from patients at local hospitals. The naphthoquinones used in this review are presented in Table I, and their origins, the techniques used for the measurement of antifungal activity (MD or DM) and type of Candida spp. are shown.

\section{A SELECTION OF RESULTS OBTAINED WITH THE MOST ACTIVE NAPHTHOQUINONES}

Plumbagin $(9$, Figure 3$)$ is a natural naphthoquinone investigated as an antifungal compound that can be isolated from plants of the families Plumbaginaceae (Paiva 2003), Droseraceae and Ebenceae. It has potent biological activities including antiinflammatory, antiparasitic and anticancer (Padhye et al. 2012) activities. This naphthoquinone was tested against $C$. albicans ATCC 10231 and showed a MIC of $0.78 \mu \mathrm{g} / \mathrm{mL}$ and a minimum fungicidal concentration (MFC) of $1.56 \mu \mathrm{g} / \mathrm{mL}$. It is well established that if the ratio MFC/MIC is lower than 4 , the microorganism will die (the compound acts as a fungicide), and if MFC/MIC is greater than 4, the compound is fungistatic (Hazen 1998, Elansary et al. 2016). The MFC/MIC ratio for 26 is 2, indicating that plumbagin (9) can be classified as a fungicide against $C$. albicans ATCC 10231. In addition, Gwee et al. (2014) obtained plumbagin (9) from fresh leaf extracts of Nepenthes gracilis Korth. (Nepenthaceae) and found MIC (MFC) values of $2 \mu \mathrm{g} / \mathrm{mL}(2 \mu \mathrm{g} / \mathrm{mL})$ for $C$. albicans ATCC 90028 and $8 \mu \mathrm{g} / \mathrm{mL}(16 \mu \mathrm{g} / \mathrm{mL})$ for $C$. parapsilosis using amphotericin B as a standard drug. They calculated selectivity indices (SIs) of 0.30 for C. albicans and 0.08 for C. parapsilosis.

Plumbagin (9) was also tested as an antimicrobial agent using an ex vivo porcine ear skin infection model against $S$. aureus and $C$. 
TABLE I

List of naphthoquinones, their origins, the techniques used for the measurement of their antifungal activity (disc diffusion method (DM) and/or the microdilution method (MD)) and the Candida spp used (Legend: NQ = Naphthoquinone; NP= Natural product; $S=$ Synthesis).

\begin{tabular}{|c|c|c|c|c|}
\hline Core NQ & Origin of NQ & Techniques & Used species & Reference \\
\hline 1,4-NQ & NP & MD & C. albicans & Elansary et al. 2016 \\
\hline 1,4-NQ & NP & MD & $\begin{array}{c}\text { C. albicans, } C . \\
\text { parapsilosis }\end{array}$ & Gwee et al. 2014 \\
\hline $1,4-\mathrm{NQ}$ & NP & MD & C. albicans (7 strains) & Hassan et al. 2016 \\
\hline $1,4-\mathrm{NQ}$ & NP & $\mathrm{MD} / \mathrm{DM}$ & C. albicans & Inouye et al. 2006 \\
\hline 1,4-NQ & NP & $\mathrm{MD} / \mathrm{DM}$ & C. albicans & Ioset et al. 2000 \\
\hline 1,4-NQ & NP & MD & $\begin{array}{c}\text { C. albicans, C. tropicalis, } \\
\text { C. parapsilosis }\end{array}$ & Naira et al. 2016 \\
\hline 1,4-NQ & NP & MD & C. albicans & Paiva et al. 2003 \\
\hline 1,4-NQ & S & MD & $\begin{array}{l}\text { C. albicans (6 strains), } C \text {. } \\
\text { glabrata, C. krusei }\end{array}$ & Allochio Filho et al. 2016 \\
\hline 1,4-NQ & S & MD & C. albicans & Arasoglu et al. 2016 \\
\hline 1,4-NQ & S & MD & C. albicans & Bayrak et al. 2016 \\
\hline 1,4-NQ & $\mathrm{S}$ & MD & $\begin{array}{c}\text { C. parapsilosis, } C \text {. } \\
\text { krusei, C. lusitaniae, } C \text {. } \\
\text { tropicalis, C. albicans ( } 2 \\
\text { strains) }\end{array}$ & Castro et al. 2013 \\
\hline 1,4-NQ & S & MD & C. krusei, C. paraosilosis & Sanchez-Calvo et al. 2016 \\
\hline $1,4-\mathrm{NQ}$ & S & MD & C. albicans & Tandon et al. $2004 b$ \\
\hline 1,4-NQ & S & DM & C. albicans & Pawar et al. 2012 \\
\hline $1,4-\mathrm{NQ}$ & S & DM & C. albicans & Shinde and Wadekar 2015 \\
\hline 1,4-NQ & S & $\mathrm{DM}$ & C. albicans & Sritrairat et al. 2011 \\
\hline 1,4-NQ & S & $\mathrm{MD} / \mathrm{DM}$ & C. tenuis & Ibis et al. 2014 \\
\hline 1,4-NQ & $\mathrm{S}$ & $\mathrm{MD} / \mathrm{DM}$ & C. tenuis & Ibis et al. 2013a \\
\hline $1,4-\mathrm{NQ}$ & $\mathrm{S}$ & $\mathrm{MD} / \mathrm{DM}$ & C. tenuis & Ibis et al. 2011 \\
\hline 1,2-NQ & S & MD & C. albicans & Khasiyatullina et al. 2009 \\
\hline $\begin{array}{l}\text { Dihydrofuran-1,2 and } \\
\text { Dihydrofuran-1,4-NQ }\end{array}$ & S & $\mathrm{MD} / \mathrm{DM}$ & $\begin{array}{c}\text { C. albicans (2 strains), } \\
\text { C. krusei, C. kefyr, C. } \\
\text { parapsilosis, C. tropicalis, } \\
\text { C. dubliniensis }\end{array}$ & Freire et al. 2010 \\
\hline Amino-1,4-NQ & NP & DM & C. albicans & Zhang et al. 2007 \\
\hline Amino-1,4-NQ & $\mathrm{S}$ & MD & $\begin{array}{l}\text { C. albicans, } C \text {. } \\
\text { parapsilosis }\end{array}$ & Tandon et al. 2009a \\
\hline Amino-1,4-NQ & S & MD & $\begin{array}{c}\text { C. albicans, } C \text {. } \\
\text { parapsilosis }\end{array}$ & Tandon et al. 2006 \\
\hline Amino-1,4-NQ & S & MD & $\begin{array}{l}\text { C. albicans, } C \text {. } \\
\text { parapsilosis }\end{array}$ & Tandon et al. 2005a \\
\hline Amino-1,4-NQ & S & MD & $\begin{array}{l}\text { C. albicans, } C \text {. } \\
\text { parapsilosis }\end{array}$ & Tandon et al. 2005b \\
\hline Amino-1,4-NQ & $\mathrm{S}$ & MD & C. albicans & Tuyun et al. 2015 \\
\hline Amino-1,4-NQ & S & MD & C. albicans & Leyva et al. 2016 \\
\hline Amino-1,4-NQ & $\mathrm{S}$ & MD & C. albicans & Sharma et al. 2013 \\
\hline
\end{tabular}


TABLE I (continuation)

\begin{tabular}{|c|c|c|c|c|}
\hline Core NQ & Origin of NQ & Techniques & Used species & Reference \\
\hline $\begin{array}{l}\text { Amino-1,4-NQ and } \\
\text { Thio-1,4-NQ }\end{array}$ & $\mathrm{S}$ & MD & $\begin{array}{l}\text { C. albicans, } C \text {. } \\
\text { parapsilosis }\end{array}$ & Tandon et al. 2009b \\
\hline Amino-1,4-NQ & S & MD & C. tenuis & Rutkauskas et al. 2013 \\
\hline Amino-1,4-NQ & S & $\mathrm{MD} / \mathrm{DM}$ & C. tenuis & Deniz et al. 2015 \\
\hline Amino-1,4-NQ & S & $\mathrm{MD} / \mathrm{DM}$ & C. albicans, C. tropicalis & Errante et al. 2006 \\
\hline Amino-1,4-NQ & S & $\mathrm{MD} / \mathrm{DM}$ & C. tenuis & Ibis et al. 2015 \\
\hline Amino-1,4-NQ & S & $\mathrm{MD} / \mathrm{DM}$ & C. tenuis & Ibis et al. 2013b \\
\hline Amino-1,4-NQ & S & $\mathrm{MD} / \mathrm{DM}$ & C. tenuis & Mickeviciene et al. 2015 \\
\hline Amino-1,4-NQ & S & $\mathrm{MD} / \mathrm{DM}$ & C. albicans, C. tropicalis & Pawar et al. 2014 \\
\hline Amino-1,4-NQ & S & $\mathrm{MD} / \mathrm{DM}$ & C. albicans & Sreelatha et al. 2014 \\
\hline Amino-1,4-NQ & S & $\mathrm{MD} / \mathrm{DM}$ & C. tenuis & Vaickelioniene et al. 2011 \\
\hline Amino-1,4-NQ & S & DM & C. tenuis & Voskiene et al. 2012 \\
\hline Amino-1,4-NQ & S & DM & C. tenuis & Voskiene et al. 2011 \\
\hline Amino-1,4-NQ & S & $\mathrm{DM}$ & C. tenuis & Buchkevych et al. 2012 \\
\hline Amino-1,4-NQ & S & $\mathrm{DM}$ & C. tenuis & Figurka et al. 2015 \\
\hline Furan-1,4-NQ & S & MD & $\begin{array}{c}\text { C. albicans, C. tropicalis, } \\
\text { C. krusei }\end{array}$ & Ryu and Chae 2005 \\
\hline Furan-1,4-NQ & S & MD & $\begin{array}{l}\text { C. albicans (2 strains), C. } \\
\text { krusei, C. glabrata } \\
\text { C. parapsilosis (2 strains) }\end{array}$ & Santos et al. 2010 \\
\hline Furan-1,4-NQ & $\mathrm{S}$ & MD & C. albicans & Yamashita et al. 2009 \\
\hline Aryl-1,4-NQ & S & $\mathrm{MD} / \mathrm{DM}$ & $\begin{array}{l}\text { C. albicans, } C \text { krusei; } C \text {. } \\
\text { glabrata, C. tropicalis }\end{array}$ & Louvis et al. 2016 \\
\hline Aryl-1,4-NQ & S & MD & C. albican, C. parapsilosis & Tandon et al. 2011 \\
\hline Alkyl-1,4-NQ & NP & MD & $\begin{array}{c}\text { C. albicans, } C \text {. glabrata, } \\
\text { C. krusei, C. tropicalis; } C \text {. } \\
\text { parapsilosis }\end{array}$ & Sasaki et al. 2002 \\
\hline Alkyl-1,4-NQ & $\mathrm{NP}$ & $\mathrm{DM}$ & C. albicans (4 strains) & Sidjui et al. 2014 \\
\hline Alkyl-1,4-NQ & $\mathrm{S}$ & MD & C. tenuis & Choudhari et al. 2017 \\
\hline Pyran-1,2-NQ & S & MD & C. albicans (2 strains) & Curvelo et al. 2015 \\
\hline Pyran-1,2- NQ & S & MD & $\begin{array}{l}\text { C. albicans (11 strains), } C . \\
\text { parapsilosis ( } 9 \text { strains) }\end{array}$ & Ferreira et al. 2014 \\
\hline Pyran-1,4-NQ & NP & $\mathrm{MD} / \mathrm{DM}$ & C. albicans & Lu et al. 2016 \\
\hline Pyran-1,4-NQ & $\mathrm{S}$ & MD & C. albicans & Jardosh and Patel 2013 \\
\hline Pyran-1,4-NQ & S & MD & C. albicans & Rao et al. 2016 \\
\hline Pyrrolidine-1,4-NQ & S & $\mathrm{MD} / \mathrm{DM}$ & C. albicans & Bhaskar et al. 2012 \\
\hline Halogen-1,4-NQ & S & $\mathrm{MD} / \mathrm{DM}$ & C. albicans (2 strains) & Tran et al. 2009 \\
\hline Thio-1,4-NQ & S & MD & C. albicans & Huang et al. 2002 \\
\hline Thio-1,4-NQ & S & MD & $\begin{array}{c}\text { C. albicans, C. tropicalis, } \\
\text { C. krusei }\end{array}$ & Ryu et al. 2005 \\
\hline Thio-1,4-NQ & S & MD & C. albicans & Tandon et al. 2004a \\
\hline Thio-1,4-NQ & S & MD & C. albicans & Yildirim et al. 2017 \\
\hline Thio-1,4-NQ & S & $\mathrm{MD} / \mathrm{DM}$ & C. tenuis & Ibis et al. 2016 \\
\hline
\end{tabular}


TABLE I (continuation)

\begin{tabular}{ccccc}
\hline Core NQ & Origin of NQ & Techniques & Used species & Reference \\
\hline Thio-1,4-NQ & $\mathrm{S}$ & $\mathrm{MD} / \mathrm{DM}$ & C. albicans, C. tropicalis & Wittebolle et al. 2006 \\
Thio-1,4-NQ & $\mathrm{S}$ & $\mathrm{DM}$ & C. albicans & Rău et al. 2016 \\
Anthraquinone & $\mathrm{NP}$ & $\mathrm{MD}$ & $\begin{array}{l}\text { C. albicans, } \text { C. krusei, } \text { C. } \\
\text { gabrata }\end{array}$ & Eyong et al. 2006 \\
Anthraquinone & $\mathrm{S}$ & $\mathrm{MD}$ & C. albicans (2 strains) & Shrestha et al. 2017 \\
\hline
\end{tabular}

albicans. The results showed that both $S$. aureus and $C$. albicans showed viability, and $\mathbf{2 6}$ broke up mono- and polymicrobial biofilms in glass tubes as well as in urinary catheter silicon tubes. Biofilm disruption was also observed when $S$. aureus and C. albicans were allowed to adhere to silicon urinary catheter tubes and were then treated with plumbagin, but the effect was stronger in glass tubes (Naira et al. 2016).

Interestingly, many metal complexes have been designed and tested as therapeutic targets. Recently, Shinde and Wadekar, in an effort to discover effective antifungal agents, synthesized a plumbagin Sm(III) complex and tested it against $C$. albicans NCIM - 3471 (Shinde and Wadekar 2015). Plumbagin (9) and its Sm(III) complex showed significant antifungal activity, but plumbagin alone showed a higher activity than the plumbagin Sm(III) complex.

Antifungal combination is a challenging but promising strategy for inhibiting the proliferation of fungi and other microorganisms. Very recently, Hassan and co-workers (Hassan et al. 2016) reported the in vitro antimicrobial effect of a combination of plumbagin (9) and amphotericin B against clinical isolates of $C$. albicans from patients with vaginal yeast infections and $C$. albicans ATCC 10231. Plumbagin exhibited inhibitory activities against all tested strains of $C$. albicans with values ranging from 7.41 to $11.24 \mu \mathrm{g} / \mathrm{mL}$. An additive antifungal activity was observed when $\mathbf{2 6}$ was used in combination with amphotericin B against C. albicans ATCC 10231 and in four clinical isolates with MICs ranging from 0.62 to $0.91 \mu \mathrm{g} /$
$\mathrm{mL}$. Based on the results, the authors suggest that the proportion of plumbagin to amphotericin B plays an important role in the additive antifungal interaction.

Bis-naphthoquinone 10 (Figure 3), which has two naphthoquinones moieties, was isolated from Ceratostigma plumbaginoides and showed potent activity against $C$. albicans ATCC 25555 (MIC of $0.09 \mu \mathrm{g} / \mathrm{mL}$ and MFC of $0.17 \mu \mathrm{g} / \mathrm{mL}$ ) using fluconazole and ketoconazole as standard drugs (Elansary et al. 2016).

Hybrid naphthoquinone-anthraquinone 11 (Figure 3), newbouldiaquinone A, was isolated from the bark of Newbouldia laevis SEEM root. (Bignoniaceae). The antimicrobial activities of this compound against $C$. albicans, $C$. glabrata and $C$. krusei were evaluated. It showed potent activities with $C$. gabrata being the most sensitive yeast. Newbouldiaquinone $\mathrm{A}$ is 13-times more active against $C$. gabrata than nystatin (Eyong 2006).

The naphthoquinones deoxyshikonin (12), acetylshikonin (13), $\beta$-hydroxyisovalerylshikonin (13) and shikonin (14) were isolated from the chloroform extract of the roots of Lithospermum erythrorhizon (Boraginaceae, Figure 3). These compounds were assayed against $C$. albicans YFC497, YFC803 (azole-resistant), C. glabrata YFC 501, C. krusei YFC 827, C. tropicalis YFC 052, and $C$. parapsilosis YFC 826. Shikonin (15) was found to have a four-fold stronger fungicide activity (MIC $4 \mu \mathrm{g} / \mathrm{mL}$ ) than fluconazole. Deoxyshikonin (12) also exhibited four-fold stronger activity against C. krusei (MIC $4 \mu \mathrm{g} / \mathrm{mL}$ ). Acetylshikonin (13) and $\beta$-hydroxyisovalerylshikonin (14) showed lower activities against all fungal pathogens 
<smiles>CC1=CC(=O)c2c(O)cccc2C1=O</smiles>

09<smiles>O=C1C(O)=C(C2=C(O)C(=O)c3cccc(O)c3C2=O)C(=O)c2c(O)cccc21</smiles>

10<smiles>Cc1cc2c(cc1OC1=C(O)C(=O)c3ccccc3C1=O)C(=O)c1ccccc1C2=O</smiles><smiles>CC(C)=CCCC1=CC(=O)c2c(O)ccc(O)c2C1=O</smiles>

12<smiles>CC(=O)O[C@@H](CC=C(C)C)C1=CC(=O)c2c(O)ccc(O)c2C1=O</smiles><smiles>CC(C)=CC[C@H](OC(=O)CC(C)(C)O)C1=CC(=O)c2c(O)ccc(O)c2C1=O</smiles>

14<smiles>CC(C)=CC[C@H](O)C1=CC(=O)c2c(O)ccc(O)c2C1=O</smiles>

15<smiles>O=C1C=C(Cl)C(=O)c2c(O)ccc(O)c21</smiles>

16<smiles>COc1ccc(OC)c2c1C(=O)C=CC2=O</smiles>

17<smiles>CCCCC(=O)Oc1cccc2c1C(=O)C=CC2=O</smiles>

18<smiles>CC(=O)Oc1ccc(OC(C)=O)c2c1C(=O)C(Cl)=C(Cl)C2=O</smiles>

19<smiles>O=C1C(Br)=C(Br)C(=O)c2c(O)ccc(O)c21</smiles>

20

Figure 3 - Some naphthoquinones active against C. krusei and C. parapsilosis.

than fluconazole except for C. krusei. 13 and 14 were also assayed against azole-resistant $C$. albicans YFC 830, but they presented the same antifungal activity as that of fluconazole (Sasaki et al. 2002). Recently, a series of compounds including 34 naphthoquinones were synthesized, and their in vitro antifungal activities against $C$. krusei and C. parapsilosis (Sánchez-Calvo el al. 2016) were screened and compared to the activity of the standard drug Amphotericin B. Some of the compounds showed potent activity against $C$. krusei. Among them, 2-chloro-5,8-dihydroxy-1,4naphthoquinone (16) was the most active compound against $C$. krusei with an MIC of $2 \mu \mathrm{g} / \mathrm{mL}$, which is similar to that of amphotericin B. It is worth noting that 5,8-dimethoxy-1,4-naphthoquinone (17), 5-pentanoyl-juglone (18), 2,3-dichloro5,8-diacethoxy-1,4-naphthoquinone (19) and 2,3-dibromo-5,8-dihydroxy-1,4-naphthoquinone (20) also have moderate activity against the same fungus (Figure 3).

Lawsone (13) is a naturally occurring naphthoquinone that can be obtained from the extract of dried powdered leaves of henna Lawsonia spp. It is commercially available and has been used as a starting material for the synthesis of many new compounds (Jordão et al. 2015). A series of thirteen Mannich adducts and different aldehydes were prepared from lawsone and evaluated as antifungal agents (Allochio Filho et al. 2016) against three Candida strains (C. albicans ATCC 10231, C. glabrata ATCC 2001 and C. krusei ATCC 34135) and five clinical C. albicans isolates from patients. Among all the compounds, the best antifungal activities were observed against $C$. albicans ATCC 10231 with the compounds 21, 22 and 23 (Figure 4). They showed activities (MICs) in the 20 to $330 \mu \mathrm{g} / \mathrm{mL}$ range. Compounds 21 and 23 showed fungistatic activity against $C$. glabrata, and compound 23 presented an MIC of $330 \mu \mathrm{g} / \mathrm{mL}$ against $C$. krusei. In addition, regarding clinical strains, compound 21 showed the best fungistatic activity against clinical $C$. albicans with MICs ranging from 40 to $670 \mu \mathrm{g} / \mathrm{mL}$. 
Following the premise that compounds with a 1,4-naphthoquinone core have promising antifungal activity, a series of halogenated naphthoquinone derivatives was synthesized, and their in vitro antifungal activities against $C$. albicans ATCC 10231 and C. albicans 955 were evaluated using an MD assay (Tran et al. 2009), and the results were compared with clotrimazole. The results showed that three compounds were quite active against $C$. albicans ATCC 10231. It should be noted that compounds 24 (MIC $1 \mu \mathrm{g}$ / $\mathrm{mL}$ ), 25 (MIC $4 \mu \mathrm{g} / \mathrm{mL}$ ) had better activities than compound 26 (MIC $8 \mu \mathrm{g} / \mathrm{mL}$ ), and they had similar antifungal profiles as clotrimazole. Compounds $\mathbf{2 4}$ and 25 (Figure 4) had potent antifungal activities against C. albicans 955 (MIC $0.25 \mu \mathrm{g} / \mathrm{mL}$ and 32 $\mu \mathrm{g} / \mathrm{mL}$, respectively). Notably, the substituents on the 1,4-naphthoquinone core are also impact in the activity, probably by modifying the redox potential of the naphthoquinone or changing its physical-chemical properties (Pawar 2014). These compounds were evaluated against $C$. tropicalis NCIM 3548 and C. albicans NCIM 3557. All the compounds (24-30, Figure 4) exhibited fungicidal activity towards all the tested fungi with MICs ranging from $0.025 \mu \mathrm{g} / \mathrm{mL}$ to $1.25 \mu \mathrm{g} / \mathrm{mL}$ for all strains. Compound 27 (Figure 4) showed better antifungal activity than amphotericin B (MIC $1.25 \mu \mathrm{g} / \mathrm{mL}$ for $C$. albicans and C. tropicalis) and nitrofurantoin (31, MIC $1.25 \mu \mathrm{g} / \mathrm{mL}$ for C. albicans and C. tropicalis).

As noted above, plumbagin (9) is an important natural naphthoquinone with well-established antifungal activity. Following these studies, another natural product known as juglone (66, 5-hydroxy1,4-naphthoquinone, Figure 5), which is isolated from plants of the Juglandaceae family, particularly black walnut (Juglans nigra), was investigated. 66 has potential uses in medicine and as a biocide for organic farming and pest control. Juglone can be synthesized by several methods and can be used as a starting material for many synthetic transformations. Reactions of juglone (56) with arylamines, arylthiols or halogens occur easily on the naphthoquinone moieties, producing several derivatives such as 39-55. These substituents can enhance the biological efficacies of the compounds.

Tandon and coworkers demonstrated the synthesis of novel 1,4-naphthoquinone derivatives with alkyl or arylthio substituents at the 2 position, such as 1,4-naphthoquinone 39 and 2,3-disubstituted 1,4-naphthoquinone 40, and tested against various strains of pathogenic fungi, such as C. albicans, $C$. neoformans, S. schenckii, T. mentagraphytes, $M$. cannis and A. fumigatus. The antifungal activities of these compounds were compared with the activities of miconazole, nystatin and amphotericin B. Compounds 39 (MIC $3.125 \mu \mathrm{g} / \mathrm{mL}$ ) and 40 (MIC $25 \mu \mathrm{g} / \mathrm{mL}$, Figure 5) presented better activities against $C$. albicans than miconazole (MIC $25 \mu \mathrm{g}$ / $\mathrm{mL}$ for $C$. albicans). Comparison of the activities of the compounds to that of nystatin (MIC 7.8-7.9 $\mu \mathrm{g} / \mathrm{mL}$ for C. albicans) showed that compound 39 was more active against $C$. albicans than nystatin (Tandon et al. 2004a). In another study, Tandon and co-workers (Tandon et al. 2004b) described a series of sulfur-containing 1,4-naphthoquinone derivatives that inhibit fungal growth with MICs in the same range as well-established antifungal drugs. The antifungal properties of the compounds were determined against the same strains of pathogenic fungi. The results showed that compounds $\mathbf{4 1 ,} 42$ and $\mathbf{4 3}$ possess pronounced antifungal activities (Figure 5). The comparison of the activities of 41, 42 and $\mathbf{4 3}$ to that of miconazole (MIC $25 \mu \mathrm{g}$ / $\mathrm{mL}$ for $C$. albicans) revealed that compounds $\mathbf{4 1}$ (MIC $12.5 \mu \mathrm{g} / \mathrm{mL}$ ) and 43 (MIC $3.125 \mu \mathrm{g} / \mathrm{mL}$ ) are more effective against $C$. albicans, and compound 42 (MIC $1.56 \mu \mathrm{g} / \mathrm{mL}$ ) is more active against $C$. neoformans and possesses the same activity profile as that of miconazole against $C$. albicans. In this work, the antifungal activities of compounds $\mathbf{4 1}$, 42 and $\mathbf{4 3}$ were compared to that of nystatin (MIC 7.8-7.9 $\mu \mathrm{g} / \mathrm{mL}$ ), and $\mathbf{4 3}$ showed activity against 
<smiles>O=C1C(O)=C(C(c2ccccc2O)N2CC3CCC2C3)C(=O)c2ccccc21</smiles>

21<smiles>[R]C1=C(Cl)C(=O)c2ccccc2C1=O</smiles>

25, $\mathrm{R}=\mathrm{N}\left(\mathrm{COCH}_{3}\right)_{2}$

26, $\mathrm{R}=\mathrm{NHCOEt}$

27, $\mathrm{R}=\mathrm{NHCH}_{3}$

28, $\mathrm{R}=\mathrm{NHEt}$

29, $\mathrm{R}=\mathrm{NHPr}$

$30, \mathrm{R}=\mathrm{NHBu}$<smiles>[R]c1cccc(SC2=C(Cl)C(=O)c3ccccc3C2=O)c1</smiles>

32, $\mathrm{R}=\mathrm{Ph}$

33, $\mathrm{R}=\mathrm{OCH}_{3}$

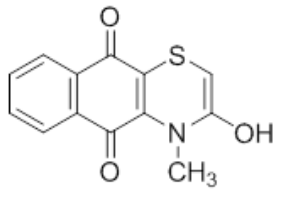

36<smiles>[R]c1cc(N([R3])C2=C(Cl)C(=O)c3ccccc3C2=O)c([R])cc1O</smiles>

34<smiles>CN1CCN(C2=C(Cl)C(=O)c3ccccc3C2=O)CC1</smiles>

37<smiles>O=C1C(O)=C(C(Nc2ccc([N+](=O)[O-])cc2)c2ccccc2O)C(=O)c2ccccc21</smiles>

23<smiles>O=C1CN(/N=C/c2ccc([N+](=O)[O-])o2)C(=O)N1</smiles><smiles>CCOC(=O)C1=NNC2C(=O)c3ccccc3C(=O)C12</smiles>

35<smiles>O=C1C(Cl)=C(N2CCCCC2)C(=O)c2ccccc21</smiles>

38

Figure 4 - a (Entry $21-23)$ - 1,4-Napthoquinone Mannich adducts active against $C$. albicans ATCC 10231; b (Entry 24 - 31) - 3-Chloro-1,4-naphthoquinones evaluated against C. albicans ATCC 10231; c (Entry 32 - 38) - 1,4-Naphthoquinones with good antifungal activities against $C$. albicans.

C. albicans more than twice that of nystatin. In conclusion, the promising inhibitory effects of sulfide 1,4-naphthoquinones were demonstrated, and the activity of compound $\mathbf{4 3}$ against a number of fungi was found to be substantial. In addition to this, Ryu et al. (2005) prepared a series of 5-hydroxy- or 5-methoxy-1,4-naphthoquinones and tested those classes of compounds against C. albicans and C. tropicalis using amphotericin $\mathrm{B}$ as the reference drug (MIC $0.25 \mu \mathrm{g} / \mathrm{mL}$ for $C$. albicans and $0.5 \mu \mathrm{g} / \mathrm{mL}$ for $C$. tropicalis, Figure 5). The results showed that the most active compounds were substituted arylthio derivatives of juglone (44-47). Compounds such as 44 (MIC $2 \mu \mathrm{g} / \mathrm{mL}$ ), 45 (MIC $4 \mu \mathrm{g} / \mathrm{mL}$ ), 46 (MIC $0.5 \mu \mathrm{g} / \mathrm{mL}$ ) and 47 (MIC $0.5 \mu \mathrm{g} / \mathrm{mL}$ ) have activities comparable to that of amphotericin B against C. tropicalis. It is worth noting that compounds 44 and 47 , which contain 4-fluoro-phenylthio substituents, exhibited potent antifungal activity. In addition to this, 3-arylamino-5-methoxy-1,4-naphthoquinones 4855 (Ryu and Chae 2005) showed potent antifungal activity against all tested fungi species, but their activities against $C$. tropicalis were highest. Many of these compounds had more potent antifungal activities against $C$. tropicalis than ketoconazole. It is interesting to note that compound $\mathbf{5 1}$ was more active against $C$. albicans KCCM 50235, C. tropicalis KCCM 50662 and C. krusei KCCM 11655 (MIC 6.3, 0.8 and $6.3 \mu \mathrm{g} / \mathrm{mL}$, respectively) than ketoconazole (MIC 6.3, 6.3 and $12.5 \mu \mathrm{g} / \mathrm{mL}$, respectively). 


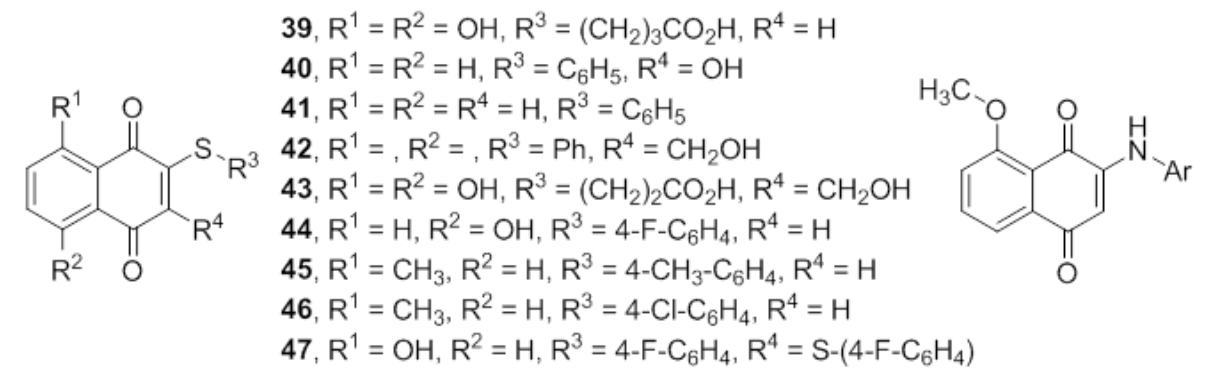

48, $\mathrm{Ar}=4-\mathrm{CH}_{3}-\mathrm{C}_{6} \mathrm{H}_{4}$

49, $\mathrm{Ar}=4-\mathrm{Br}-\mathrm{C}_{6} \mathrm{H}_{4}$

$50, \mathrm{Ar}=4-\mathrm{F}-\mathrm{C}_{6} \mathrm{H}_{4}$

51, $\mathrm{Ar}=4-\mathrm{Cl}-\mathrm{C}_{6} \mathrm{H}_{4}$

52, $\mathrm{Ar}=2,3,4-\mathrm{F}-\mathrm{C}_{6} \mathrm{H}_{3}$

53, $\mathrm{Ar}=3,4-\mathrm{F}-\mathrm{C}_{6} \mathrm{H}_{3}$

$54, \mathrm{Ar}=2-\mathrm{F}-\mathrm{C}_{6} \mathrm{H}_{4}$

55, $\mathrm{Ar}=2,4-\mathrm{F}-\mathrm{C}_{6} \mathrm{H}_{3}$<smiles>O=C1C=CC(=O)c2c(O)cccc21</smiles><smiles>[R][R](=O)[Se][Se][R](C)=O</smiles><smiles>[R]c1ccc(SC2=C(SC(=C)C)C(=O)c3ccccc3C2=O)cc1</smiles>

58, $\mathrm{R}=\mathrm{CH}_{3}$ 59, $\mathrm{R}=\mathrm{OCH}_{3}$<smiles>[R]c1ccc(NC2=C(S(=O)c3ccccc3)C(=O)c3ccccc3C2=O)cc1</smiles>

$60, \mathrm{R}=\mathrm{H}$

$65, \mathrm{R}=\mathrm{H}$

61, $\mathrm{R}=\mathrm{Cl}$
$62, \mathrm{R}=\mathrm{Br}$

63, $\mathrm{R}=\mathrm{OCH}_{3}$

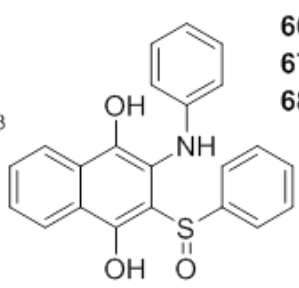

66, $\mathrm{R}=\mathrm{Br}$

$67, \mathrm{R}=\mathrm{NO}_{2}$

$68, \mathrm{R}=\mathrm{CH}_{3}$

$64, \mathrm{R}=\mathrm{NO}_{2}$

$$
\begin{aligned}
& 72, \mathrm{R}^{1}=\mathrm{H}, \mathrm{R}^{2}=\mathrm{H} \\
& 73, \mathrm{R}^{1}=\mathrm{S}-\left(4-\mathrm{OCH}_{3}-\mathrm{C}_{6} \mathrm{H}_{4}\right), \mathrm{R}^{2}=\mathrm{H} \\
& 74, \mathrm{R}^{1}=\mathrm{S}-\left(4-\mathrm{NO}_{2}-\mathrm{C}_{6} \mathrm{H}_{4}\right), \mathrm{R}^{2}=\mathrm{H} \\
& 75, \mathrm{R}^{1}=\mathrm{S}-\left(\mathrm{C}_{6} \mathrm{H}_{5}\right), \mathrm{R}^{2}=\mathrm{H} \\
& 76, \mathrm{R}^{1}=\mathrm{S}-\left(4-\mathrm{CH}_{3}-\mathrm{C}_{6} \mathrm{H}_{4}\right), \mathrm{R}^{2}=\mathrm{H} \\
& 77, \mathrm{R}^{1}=\mathrm{S}-\left(4-\mathrm{OCH}_{3}-\mathrm{C}_{6} \mathrm{H}_{4}\right), \mathrm{R}^{2}=\mathrm{OCH}_{3} \\
& 78, \mathrm{R}^{1}=\mathrm{S}-\left(4-\mathrm{CH}_{3}-\mathrm{C}_{6} \mathrm{H}_{4}\right), \mathrm{R}^{2}=\mathrm{CH}_{3}
\end{aligned}
$$

Figure 5 - a (Entry 39 - 56) - Some naphthoquinones active against C. albicans, C. neoformans, S. schenckii, T. mentagraphytes, M. cannis and A. fumigatus; b (Entry 57 - 78) - Sulfides, sulfoxide and amino-1,4-naphthoquinones with activity against some Candida strains.

In their continuing effort to find new potent 1,4-naphthoquinone analogs, Tandon and coworkers developed new routes for preparing 1,4-naphthoquinones substituted at $\mathrm{C} 2$ and $\mathrm{C} 3$. The antifungal activities of these compounds (Figure 4) have been evaluated against $C$. albicans and $C$. parapsilosis ATCC 22019. The antifungal activity was compared with standard drugs like miconazole. The research published in 2005 evaluated the antifungal activity of 10 naphthoquinones and compound $\mathbf{3 5}$ was found to have the most potent activity against $C$. albicans (MIC $6.26 \mu \mathrm{g} / \mathrm{mL}$ ) (Tandon et al 2005a). Years later, the authors present the results of a new research with other group of Amino-1,4-naphthoquinones and Thio1,4- naphthoquinones. Compound 32 (MIC 6.25 $\mu \mathrm{g} / \mathrm{mL}$ ) was found to have better activity against $C$. albicans than miconazole (MIC $25 \mu \mathrm{g} / \mathrm{mL}$ ), and $\mathbf{3 3}$ showed the same activity as miconazole (Tandon et al. 2009b). In the same work, they reported the synthesis of novel nitrogen- and sulfur-containing 1,4-naphthoquinones and the evaluation of their antifungal activities. Among the most promising antifungal compounds of this series, only $\mathbf{3 4}$ showed the same antifungal activity against $C$. albicans (MIC $1.56 \mu \mathrm{g} / \mathrm{mL}$ ) as that of miconazole. Additionally, compounds 36 (MIC $3.00 \mathrm{mmol} /$ $\mathrm{mL}$ ), 37 (MIC $5.38 \mathrm{mmol} / \mathrm{mL}$ ), and 38 (MIC $5.66 \mathrm{mmol} / \mathrm{mL}$ ) were prepared and showed good antifungal activity against $C$. albicans (Tandon et al. 2010). Compounds 36 (MIC $6.02 \mathrm{mmol} / \mathrm{mL}$ ) and $38(11.32 \mathrm{mmol} / \mathrm{mL})$ also showed pronounced antifungal activities against $C$. parapsilosis.

Errante et al. (2006) reported a synthetic route to disulfidequinone-quinones (57-59), aminosulfoxide-quinones (60-68) and sulfidesulfoxidequinones (73-78) and studied their activities against different fungal strains. Twelve compounds 
were screened in vitro for their growth inhibitory activity against different fungi strains such as $C$. albicans CIP 884.65 and C. tropicalis CIP 1275.81. The MIC values were determined by comparison to amphotericin B as a standard. Amphotericin B was more active than all the synthesized compounds against $C$. albicans; however, compounds 57-68 (Figure 5) were all very active against $C$. tropicalis. The MICs of the synthesized molecules against $C$. albicans were substantial compared to amphotericin B. The MICs were lower than $0.2 \mu \mathrm{g} / \mathrm{mL}$ except for compound 81 which had an MIC between 0.2-0.3 $\mu \mathrm{g} / \mathrm{mL}$ for $C$. tropicalis. No clear structure-activity relationship seems to exist with these series. As an expansion of this fruitful area of research, Wittebolle et al. (2006) reported the synthesis of several derivatives of 2-benzenesulfinyl$(1,4)$-naphthoquinone (72) and evaluated them as antifungal agents against $C$. albicans and $C$. tropicalis, and they used amphotericin B as a reference. The results indicated that the compounds presented higher MICs than amphotericin B against $C$. albicans. Conversely, for $C$. tropicalis, 60-64 and 72-78 (Figure 5) all had MICs below $0.2 \mu \mathrm{g} / \mathrm{mL}$, except compound 77, which had an MIC of $0.3 \mu \mathrm{g} / \mathrm{mL}$. As a further extension of these studies, a conjugate addition of primary and secondary amines to 1,4-naphthoquinones to obtain 2-amino-1,4-naphtoquinones was developed, and the resulting compounds were tested in vitro as antifungal agents (Sharma et al. 2013). Compounds 69, 70 and 71 exhibited strong activity against $C$. albicans (MIC $15.6 \mu \mathrm{g} / \mathrm{mL}$ ), but nystatin, which was used as a standard, was much more potent (MIC $7.8 \mu \mathrm{g} / \mathrm{mL}$ for C. albicans).

Xanthene and chromene are synthetic heterocyclic scaffolds that exhibit a broad spectrum of biological properties (Forezi et al. 2017a). Several preparative approaches for this class of compounds have been described in the literature and mainly center around two or three component reactions. In their search for new antimicrobial agents, Jardosh and Patel (2013) prepared a series of xanthene-naphthoquinones and assayed them against Gram-positive and Gram-negative bacteria and tested their antifungal properties against $C$. albicans MTCC 227. The antifungal testing results revealed that compounds $\mathbf{7 9}$ and $\mathbf{8 0}$ (MIC $250 \mu \mathrm{g}$ / $\mathrm{mL}$, Figure 6) had moderate activity against $C$. albicans compared with nystatin. Spirooxindoles are synthetic or naturally occurring heterocyclic compounds with a wide range of biological activities. Combining the spirooxindole structure with a naphthoquinone can produce compounds with enhanced antifungal activities. Indeed, Bhaskar et al. (2012) reported the synthesis of 1,4-naphthoquinones fused to isatin scaffolds and sarcosine through 1,3-dipolar cycloadditions. The antimicrobial activities of these compounds were screened against eight bacteria and three fungi in vitro using the disc DM. The results revealed that most of the synthesized compounds exhibited antimicrobial activities against Staphylococcus aureus, S. aureus (MRSA), Enterobacter aerogens, Micrococcus luteus, Proteus vulgaris, Klebsiella pneumonia, Salmonella typhimurium, Salmonella paratyphi-B, Malassesia pachydermatis, $C$. albicans and Botyritis cinerea. Significant MICs were found for 1'-acetyl-2-methyl-2,3dihydrospiro[benzo[f] isoindole-1,3'-indoline]2',4,9-trione (81) against C. albicans MTCC 227. $\mathbf{8 1}$ was 1.4 times more active than ketoconazole.

Nitrogen-containing heterocycles are the most common type of heterocycles in drug structures. Analysis of the database of FDAapproved drugs revealed that $59 \%$ of the drugs contain a heterocycle with a single nitrogen (Vitaku and Njardarson 2013). Combining the 1,4-naphthoquinone system with isoxazole can lead to new bioactive compounds. In 2010, the synthesis of naphtho[2,3-d]isoxazole-4,9-diones containing an electron-withdrawing group at the 3 position was reported (Santos et al. 2010). By using 2,3-dichloro1,4-naphthoquinone (82) as a starting material 
<smiles>C=CCn1c(=O)c(C2C3=C(CCCC3=O)OC3=C2C(=O)c2ccccc2C3=O)cc2ccccc21</smiles>

79<smiles>C=CCn1c(=O)c(C2C(N)=C(N)OC3=C2C(=O)c2ccccc2C3=O)cc2ccccc21</smiles>

80<smiles>CC(=O)N1C(=O)c2ccccc2C(=O)C2=C3C(N(C)C2)C3(c2ccccc2)C1=O</smiles>

81<smiles>O=C1C(Cl)=C(Cl)C(=O)c2ccccc21</smiles>

82<smiles>Cc1ccc2oc3c(=O)c4ccccc4c(=O)c=3n(C(C)CC(=O)O)c2c1</smiles>

83, $\mathrm{R}=\mathrm{H}$

84, $\mathrm{R}=\mathrm{CH}_{3}$

$85, \mathrm{R}=\mathrm{Cl}$<smiles>[R]OC(=O)c1noc2c1C(=O)c1ccccc1C2=O</smiles>

Figure 6 - a (Entry 79 - 81) - Examples of 1,4-benzoxanthenes with antifungal activity; b (Entry $82-87$ ) - 1,4-Naphthoquinones fused to isoxazoles or phenoxazins with antifungal properties.

(Forezi et al. 2017b), it was possible to prepare eight naphthoquinone derivatives and evaluate their antifungal activities against $C$. albicans ATCC 90028, C. albicans PYCC 3436T, C. krusei PYCC 3341, C. parapsilosis PYCC 2545, C. parapsilosis ATCC 22019, C. glabrata PYCC 2418T. Among them, two naphtho[2,3- $d]$ isoxazole-4,9-dione3-carboxylates, 86 and $\mathbf{8 7}$, are more potent than amphotericin B against C. albicans, C. krusei, C. parapsilosis and C. glabrata. It is also important to note that in previous studies on this group of compounds, they were found to be non-cytotoxic to human cells (Santos et al. 2009). The authors suggest that the naphtho[2,3- $d]$ isoxazole-4,9-dione scaffold has the potential to be developed into novel and safe therapeutic antifungal agents. Recently, Mickevičienè et al. (2015) reported the synthesis and biological activity of derivatives of aromatic, heterocyclic and/or naphthoquinone fragments containing $p$-amino acids. The antifungal activities of the obtained compounds were evaluated against C. tenuis VKM Y-70 by means of DM and MD. The activities were compared to that of the antifungal agent nystatin. The 3-(2-substituted-6,11-dioxo6,11-dihydro-12H-benzo[b]phenoxazin-12-yl) butanoic acids showed the best results in this evaluation; compounds 83-85 (Figure 6) showed MICs of $15.6 \mu \mathrm{g} / \mathrm{mL}, 31.2 \mu \mathrm{g} / \mathrm{mL}$ and $31.2 \mu \mathrm{g} / \mathrm{mL}$, respectively, against $C$. tenuis VKM Y-70.

An interesting series of quaternary ammonium salts of 1,2,3-triazoles fused to naphthoquinones were synthesized and screened as antifungal agents. It is well known that amphiphilic molecules are the most commonly used antimicrobial disinfectants. Shrestha et al. (2017) synthesized cationic amphiphilic units based on aminoglycosides and 1,4-naphthoquionones. Thus, the antifungal activities of a series of synthetic dimeric cationic naphthoquinone analogs were evaluated against A. flavus, C. albicans 64124 (azole-resistant), Candida albicans MYA2876 (azole-susceptible), Cryptococcus neoformans and Rhodotorula pilimanae using Kanamycin A (K20) and fluconazole as the standards. Compounds $\mathbf{8 8}$ and $\mathbf{8 9}$ (Figure 7) exhibited excellent antifungal activities against all tested fungi, and both compounds had 
MICs of $3.91 \mu \mathrm{g} / \mathrm{mL}$ for both C. albicans 64124 (azole-resistant) and C. albicans MYA2876 (azolesusceptible). These values are at least 17 times higher than those of the standard drugs for treating C. albicans. A green fluorescence assay showed that compound $\mathbf{8 9}$ exerts its antifungal activity via a pore formation mechanism.

Freire et al. (2010) reported the synthesis and antifungal activities of substituted $\alpha$ - and $\beta$-dihydrofuran naphthoquinones prepared via the reaction of lawsone (8) with olefins in the presence of cerium (IV) ammonium nitrate (CAN). The antifungal activities these compounds were evaluated against 89 fungal cultures, including 29 opportunistic yeasts, 40 filamentous fungi and 20 opportunistic dermatophytes. The compound designated IVS320 (90, Figure 8) presented the lowest MICs for all the tested cultures and was particularly active against dermatophyte fungi (MICs ranged from 5-28 $\mu \mathrm{g} / \mathrm{mL}$ ) and yeasts from the genus Cryptococcus (MICs ranged from 3-5 $\mu \mathrm{g} / \mathrm{mL}$, Ferreira et al. 2014). IVS320 induced changes in the fungal membrane by interacting with ergosterol, but it did not alter the structure of the fungal cell wall. However, it changed the permeability of the cell membrane (as evidenced by the efflux of $\mathrm{K}^{+}$and leakage of substances), which was not related to binding with ergosterol. These results are very relevant, and this compound could be used as a starting point for the development of new antifungal agents.

Among the publications discussed in this review, only two reports involved the development of naphthoquinone-derived pharmaceutical products for the treatment of candidiasis. Several studies have already described the preparation, characterization and in vitro activity formulations of natural molecules with antifungal activity such as juglone (56) and lawsone methyl ether. Arasoglu et al. (2016) synthesize and characterize juglone (56)-entrapped Poly(lactic-co-glycolic acid) nanoparticles (PLGA nanoparticles) and compared the antifungal properties of free juglone (56) with the PLGA nanoparticle formulation. The antifungal activity was evaluated by two different methods with A. flavus, C. albicans and Fusarium spp. The antifungal studies using agar dilution and top agar dilution methods indicated that the juglone-encapsulated nanoparticles were more effective than free juglone (56). Sritrairat et al. (2011) determined the antifungal activity of lawsone methyl ether (LME) in mouthwash and compared it with that of chlorhexidine mouthwash in vitro and in vivo. The antifungal activity of LME has been reported, and it has the potential to be used after successful treatment of oral candidiasis caused by Candida spp. to delay relapse and reduce antifungal drug use. The antifungal activity of $0.25 \%$ LME was significantly greater than that of $0.12 \%$ chlorhexidine mouthwash $(\mathrm{P}<0.05)$. As an ideal antimycotic for treating oral candidiasis is not yet available, LME may be an appropriate alternative mouthwash for the prophylaxis of oral candidiasis caused by Candida spp. Despite the well-documented antifungal activity of several naphthoquinones, the real-world application of these compounds has encountered some challenges, mainly due to their low solubility in water. These studies showed that formulated products are an indication of promising antifungal activity, and product formulations may be an important tool for the successful application of these materials, especially the hydrophobic compounds, in many areas.

\section{DISCUSSION}

The increase in the incidence of deep fungal infections in the past two decades is a concern of health authorities around the world. In addition to immunocompromised patients, patients with nosocomial infections and the healthy population can experience this problem. In addition, with the rapid increase in the incidence of Candidiasis, 


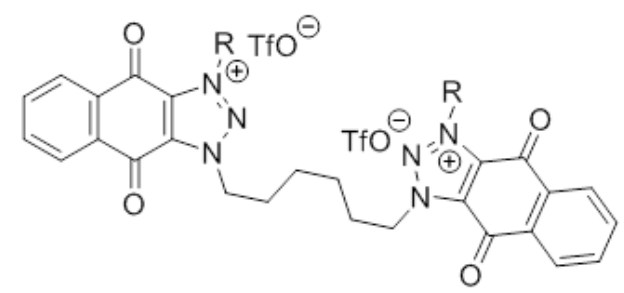

88, $\mathrm{R}=\mathrm{C}_{8} \mathrm{H}_{17}$

$89, \mathrm{R}=\mathrm{C}_{10} \mathrm{H}_{23}$

Figure 7 - (Entry $88-89)$ - Dimeric cationic naphthoquinone analogs with activities against A. flavus, C. albicans 64124, Candida albicans MYA2876, Cryptococcus neoformans and Rhodotorula pilimanae.

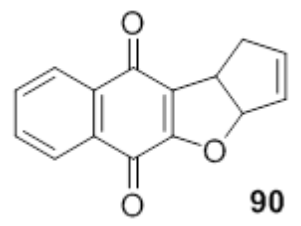

Figure 8 - (Entry 90)

- Structure of IVS320.

other Candida species and microorganisms other than C. albicans have become involved in such infections. The balance between $C$. albicans and non-Candida albicans determines the virulence profiles. Some fungal species can also form biofilms with other species which impacts their virulence (Martins et al. 2014). No new classes of antifungal drugs have been approved in the past ten years. This is problematic because current drugs are not sufficiently active, their oral administration is restricted, they have specific drug or class toxicities, or they have notable drug interactions (Denning and Bromley 2015).

The current literature confirms the urgent need for new drugs despite the effective drug treatments on the market. One strategy for the development of new drugs is the screening of antifungal drugs using samples from compound libraries (Roemer and Krysan 2014, Calderone et al. 2014). A review of scientific publications may assist in the selection of promising targets for inclusion in more detailed stages of the evaluation of biological activity.
Amphotericin B is a broad spectrum antifungal and is used for the treatment of severe infections caused by Candida species and especially for fluconazole resistant strains (Pianalto and Alspaugh 2016). The results discussed in this review indicate that three naphthoquinones are more active than amphotericin B against different strains of $C$. albicans: 27, 28 and 29 (Pawar et al. 2014). Two compounds are noteworthy due to their promising results against $C$. albicans and non-C. albicans. The naphtho[2,3-d]isoxazole-4,9-diones 86 and 87 were much more active than amphotericin B against 6 different Candida species. (Santos et al. 2010)

Regarding C. tropicalis, it has become dramatically more prevalent in several countries. It is a potential opportunistic fungus in patients with neutropenia, the suppression of bacterial flora due to the use of antibiotics, or damage to the gastrointestinal mucosa. The sulfidesulfoxidequinones, disulfidequinones and amino-sulfoxidequinones (57-68 and 72-78) presented potent activity against $C$. tropicalis with MICs less than $0.2 \mu \mathrm{g} / \mathrm{mL}$. (Errante et al. 2005) A similar result was found for a series of 2-benzenesulphinyl-(1,4)naphthoquinone derivatives, 72-78 (Wittebolle et al. 2006).

Azoles are the most commonly prescribed drugs to treat Candida spp. infections, but some Candida spp. are less susceptible to azoles, and some species develop resistance during prolonged therapy (WHO 2016). Fluconazole is the most widely prescribed azole and is very effective in the treatment of infections caused by Cryptococcus and Candida spp. Resistance to fluconazole is a significant clinical problem, as some Candida spp., such as C. krusei, are intrinsically resistant to this drug. Health authorities worldwide are warning of accurate identification of the infectious species and the use of antifungal susceptibility tests for clinically relevant isolates (Pianalto and Alspaugh 2016). 
The evaluation of antifungal activities against azole-resistant $C$. albicans species allows the selection of compounds that may become very promising drugs for the solution of this major public health problem. Naphthoquinones $\mathbf{8 8}$ and $\mathbf{8 9}$ are noteworthy for their excellent activities against strains of azole-resistant $C$. albicans. The 1,2-naphthoquinone IVS320 (90) is one of the most promising compounds among the naphthoquinones discussed in this work. It has potent activity for all Candida spp., including C. albicans, C. krusei, C. parapsilosis, C. kefyr, and C. tropicalis (Freire et al. 2010). Advances in this field have begun to build a foundation for understanding the mechanism of action of these compounds (Ferreira et al. 2014).

C. krusei is an important pathogen among patients receiving bone marrow transplants and is intrinsically resistant to fluconazole. C. krusei is recognized as a potentially multidrug resistant pathogen (MDR) because of its intrinsic resistance to fluconazole combined with both flucytosine and amphotericin B. Even with its intrinsic resistance to fluconazole, $C$. krusei may be susceptible in vitro to voriconazole. C. glabrata and C. krusei are considered indicative species and should be monitored for the development of antifungal resistance (Pfaller et al. 2008). The screening of the antifungal activities of naphthoquinones against $C$. krusei suggests new directions for the search for new antifungal compounds. The naphthoquinones isolated from roots of Lithospermum erythrorhizon, deoxyshikonin (12) and shikonin (15), showed potent activity against $C$. krusei. These compounds seem potentially useful for clinical applications (Sasaki et al. 2002).

Different mechanisms of action have already been described for these compounds in eukaryotic cells, but the main mechanism of action is probably by the formation of reactive oxygen species in the cells (Salas et al. 2011) through interactions with NADPH-cytochrome P450 reductase (Salas et al. 2011). By searching the BLAST database
(https://blast.ncbi.nlm.nih.gov/Blast.cgi), it was found that the sequences of NADPH-cytochrome P450 reductase in $C$. albicans (sequence ID: KHC77605.1) and C. glabrata (sequence ID: KTA97668.1) are quite different from that of the human enzyme (sequence ID: P16435), showing $36 \%$ and $35 \%$ of identity, respectively. Thus, it is possible to develop molecules selective and active toward fungi. Through the evaluation of toxicity using different models, some naphthoquinones that were more selective for Candida spp. than mammalian cells $\left(\mathrm{CC}_{50}>\mathrm{MIC}\right)$ were identified (Castro et al. 2013, Louvis et al. 2016, Ryu et al. 2005, Shrestha et al. 2017, Tandon et al. 2009a).

Increasing the content of intracellular reactive oxygen species in Candida spp. can cause oxidation of intracellular lipids, proteins and nucleic acids leading to problems such as (i) DNA damage; (ii) protein function alteration; (iii) disruption of mitochondrial activity; (iv) enzymatic inhibition; and (v) membrane damage (Holmström and Finkel 2014). It was shown that naphthoquinones can alter the integrity of the plasmatic membrane. Allochio Filho et al. (2016) described that C. albicans treated with 21 showed increased plasmatic membrane permeability. Additionally, Shrestha at al. (2017) demonstrated that $\mathbf{8 1}$ induced a substantial loss of plasmatic membrane integrity in C. albicans. This molecule also had a large alkyl chain, which might allow it to interact directly with the membrane.

\section{CONCLUSIONS}

During the period covered by this review, many research groups have searched for new compounds with antifungal activity. The findings discussed in this review confirm that there is strong scientific evidence for the antifungal activity of naphthoquinones against species of the genus Candida. In this 17-year period, the antifungal activities of 691 naphthoquinones were evaluated against eight Candida species with an emphasis 
on studies with C. albicans. However, only a few studies were devoted to clarifying the mechanism of action of the naphthoquinones on these fungi. Additional studies are needed to explore the mechanism behind the antifungal activities of these substances to design new and more active compounds. By evaluating the results of antifungal activity studies using the methodology proposed in this review, it was possible to identify 30 naphthoquinones that presented very promising activities; their activities were actually higher than the standard drugs. Only preliminary studies have been run on some of these compounds, so further studies are needed to clarify their mechanisms of action, metabolism and cytotoxicities on normal cells. Thus, many more biological and physicalchemical studies on these compounds are needed to develop them into new antimicrobial drugs.

\section{REFERENCES}

ACTON EM, TONG GL, MASHER CW, SMITH TH AND HENRY DW. 1979. 7(Aminoethyl) ether and thioether of daunomycinone. J Med Chem 22: 922-926.

ALLOCHIO FILHO JF ET AL. 2016. Synthesis, in vitro antifungal activity and molecular modeling studies of new Mannich bases derived from lawsone. J Braz Chem Soc 27: 2127- 2140 .

ARASOGLU T, MANSUROGLU B, DERMAN S, GUMUS B, KOCYIGIT B, ACAR T AND KOCACALISKAN I. 2016. Enhancement of Antifungal Activity of Juglone (5-Hydroxy-1,4-naphthoquinone) Using a PLGA Nanoparticle System. J Agric Food Chem 64: 7087-7094.

ASCHE C. 2005. Antitumour Quinones. Mini Rev Med Chem 449-467.

BASSI L AND PALITTI F 2000. Anti-topoisomerase drugs as potent inducers of chromosomal aberrations. Genet Mol Biol 23: 1065-1069.

BAYRAK N, YILDIRIM H, TUYUN AF, KARA EM, CELIK BO AND GUPTA GK. 2016. Synthesis, biological, and computational study of naphthoquinone derivatives containing heteroatoms. J Chem Soc Pak 38: 1211-1221.

BENDZ ZG. 1948 An antibiotic agent from Marasmius graminum. Acta Chem Scand 2: 192-192.

BENEDICT K, RICHARDSON M, VALLABHANENI S, JACKSON BR AND CHILLER T. 2017. Emmerging issues, challenges, and changing epidemiology of fungal disease outbreaks. Lancet Infect Dis 17: 30443-30447
BHASKAR G, ARUN Y, BALACHANDRAN C, SAIKUMAR C AND PERUMAL PT. 2012. Synthesis of novel spirooxindole derivatives by one pot multicomponent reaction and their antimicrobial activity. Eur J Med Chem 51: 79-91.

BINKLEY S B, MAC CORQUODALE DW, CHENWY LC, THAYER SA AND DOISY EA. 1939. The constitution and synthesis of Vitamin K1. J Biol Chem 131: 357-370.

BOOTHMAN DA, TRASK DK AND PARDEE AB. 1989. Inhibition of a potencially lethal DNA damage repair in human tumor cells by $\beta$-Lapachone, an activator of topoisomerase I. Cancer Res 49: 605-612.

BROWN GD, DENNING DW, GOW NAR, LEVITZ SM, NETEA MG AND WHITE TC. 2012. Hidden Killers: Human Fungal Infections. Sci Transl Med 4: 165rv13.

BUCHKEVYCH I, STASEVYCH M, CHERVETSOVA V, MUSYANOVYCH R AND NOVIKOV V. 2012. Synthesis, computational and antimicrobial studies of new 1,4-naphthoquinone aminothiazole derivatives. Chem Technol 3: 62-69.

BUTLER MS. 2008. Natural products to drugs: natural product-derived compounds in clinical trials. Nat Prod Rep 25: 475-516.

CALDERONE R, SUN N, GAY-ANDRIEU F, GROUTAS W, WEERAWARNA P, PRASAD S, ALEX D AND LI D. 2014 Antifungal drug discovery: the process and outcomes. Future Microbiol. 9: 791-805.

CAO S AND PENG X. 2014. Exploiting endogenous cellular process to generate quinone methides in vivo. Curr Org Chem 18: 70-85.

CASTRO FAV, MARIANI D, PANEK AD, ELEUTHERIO ECA AND PEREIRA MD. 2008. Cytotoxicity Mechanism of Two Naphthoquinones (Menadione and Plumbagin) in Saccharomyces cerevisiae. PLoS One 3: e3999.

CASTRO MA, GAMITO AM, TANGARIFE-CASTAÑO $\mathrm{V}$, ZAPATA B, CORRAL JMMD, MESA-ARANGO AC, BETANCUR-GALVIS L AND FELICIANO AS. 2013. Synthesis and antifungal activity of terpenyl-1,4naphthoquinone and 1,4-anthracenedione derivatives. Eur J Med Chem 67: 19-27.

CASTRO SL, EMERY F S AND DA SILVA JUNIOR EN. 2013. Synthesis of quinoidal molecules: strategies towards bioactive compounds with an emphasis on lapachones. Eur J Med Chem 69: 678-700.

CDC - CENTER FOR DISEASE CONTROL AND PREVENTION. 2017a. https://www.cdc.gov/fungal/ diseases/candidiasis/index.html. Accessed 20 September 2017.

CDC - CENTER FOR DISEASE CONTROL AND PREVENTION. 2017b. https://www.cdc.gov/fungal/ diseases/candidiasis/thrush/index.html. Accessed 20 September 2017. 
CHIANG J, AVERBOUKH L AND PARDEE AB. 1993. $\beta$-Lapachone, a novel DNA Topoisomerase I inhibitor with a mode of action different from camptothecin. J Biol Chem 268: $22463-22468$

CHOUDHARI D, LANDE DN, BAGADE A, GEJJI SP, CHAKRAVARTY D, KODAM KM AND SALUNKEGAWALI S. 2017. Molecular structures and biological activities of (N)-n-alkylammonium 2-chloro-3-oxido-1,4naphthoquinone salts. J Mol Struct 1145: 309-320.

CIPRIANI FA, FIGUEIREDO MR, SOARES GLG AND KAPLAN MAC. 2012. Implicações químicas na sistemática e filogenia de Bignoniaceae. Quim Nova 35: 2125-2131.

COATES CS, ZIEGLER J, MANZ K, GOOD J, KANG B, MILIKISIYANTS S, CHATTERJEE R, HAO S, GOLBECK JH AND LAKSHMI KVJ. 2013. The Structure and Function of Quinones in Biological Solar Energy Transduction: A Cyclic Voltammetry, EPR, and Hyperfine Sub-Level Correlation (HYSCORE) Spectroscopy Study of Model Naphthoquinones. J Phys Chem B 117: 72107220 .

COELHO-CERQUEIRA E, NETZ PA, CANTO VP, PINTO AC AND FOLLMER C. 2014. Beyond Topoisomerase Inhibition: Antitumor 1,4-Naphthoquinones as Potential Inhibitors of Human Monoamine Oxidase. Chem Biol Drug Des 83: 401-410.

COLOMBO AL, DE ALMEIDA JÚNIOR JN, SLAVIN MA, CHEN SCA AND SORREL TC. 2017. Candida and invasive mould diseases in non-neutropenic critically ill patients and patients with haematological cancer. Lancet Infect Dis 17(11): e344-e356.

COSERI S. 2009. Natural Products and their Analogues as Efficient Anticancer Drugs. Mini Rev Med Chem 9: 560571.

CUNHA AS, LIMA ELS, PINTO AC, ESTEVES-SOUZA A, ECHEVARRIA A, CAMARA CA, VARGAS MD AND TORRES JC. 2006. Synthesis of novel naphthoquinonespermidine conjugates and their effects on DNAtopoisomerases I and II- $\alpha$. J Braz Chem Soc 17: 439-442.

CURVELO JAR ET AL. 2015. 3-Indol carboxaldehyde, an imidazole synthesized from naphthoquinone $\beta$-lapachone downregulates Candida albicans biofilm. Med Chem Res 24: $1155-1161$.

DENIZ NG, CEMIL I, GOKMEN Z, STASEVYCH M, NOVIKOV V, KOMAROVSKA-POROKHNYAVETS O, OZYUREK M, GUCLU K, KARAKAS D AND ULUKAYA E. 2015. Design, Synthesis, Biological Evaluation and Antioxidant and Cytotoxic Activity of Heteroatom-Substituted 1,4-Naphtho- and Benzoquinones. Chem Pharm Bull 63: 1029-1039.

DENNING DW AND BROMLEY MJ. 2015 How to bolster the antifungal pipeline. Science 347: 1414.
DIOGO EBT ET AL. 2013. Synthesis and anti-Trypanosoma cruzi activity of naphthoquinone-containing triazoles: Electrochemical studies on the effects of the quinoidal moiety. Bioorg Med Chem 21: 6337-6348.

DOWD P, HAM SW, NAGANATHAN S AND HERSHLINE R. 1995. The mechanism of action of vitamin K. Annu Rev Nutr 15: 419-440

ELANSARY HO, YESSOUFOUC K, MAHMOUDD EAAND SKALICKA-WOŹNIAKE K. 2016. In vitro antioxidant and antimicrobial effects of Ceratostigma plumbaginoides. Nat Prod Commun 11: 1455-1458.

ERRANTE G, MOTTA GL, LAGANA C, WITTEBOLLE V, SARCIRON ME AND BARRET R. 2006. Synthesis and evaluation of antifungal activity of naphthoquinone derivatives. Eur J Med Chem 41: 773-778.

EYONG KO, FOLEFOC GF, KUETE V, BENG VP, KROHN K, HUSSAIN H, NKENGFACK AE, SAEFTEL M, SARITE SR AND HOERAUF A. 2006. Newbouldiaquinone A: A naphthoquinone-anthraquinone ether coupled pigment, as a potential antimicrobial and antimalarial agent from Newbouldia laevis. Phytochemistry 67: 605-609.

FAN PW AND BOLTON JL. 2001. Bioactivation of tamoxifen to metabolite e quinone methide: reaction with glutathione and DNA. Drug Metab Dispos 29: 891-896.

FERREIRA DCM, TAPSOBA I, ARBAULT S, BOURET Y, MOREIRA MSA, PINTO AV, GOULART MOF AND AMATORE C. 2008. Ex vivo activities of $\beta$-Lapachone and $\alpha$-Lapachone on macrophages: A quantitative pharmacological analysis based on amperometric monitoring of oxidative bursts by single cells. ChemBioChem 10: 528-538.

FERREIRA MPSBC, CARDOSO MFC, SILVA FC, FERREIRA VF, LIMA ES AND SOUZA JVB. 2014. Antifungal activity of synthetic naphthoquinones against dermatophytes and opportunistic fungi: preliminary mechanism-of-action tests. Ann Clin Microbiol Antimicrob 13: $26-31$.

FERREIRA RA, OLIVEIRA ABM, GUALBERTO SA AND VITOR RW. 2002. Activity of natural and synthetic naphthoquinones against Toxoplasma gondii, in vitro and in murine models of infection. Parasite 9: 261-269.

FERREIRA SB, DA SILVA FC, PINTO AC, GONZAGA DTG AND FERREIRA VF. 2009. Syntheses of chromenes and chromanes via o-quinone methide intermediates. J Heterocycl Chem 46:1080-1097.

FERREIRA SB, GONZAGA DTG, SANTOS WC, ARAÚJO KGL AND FERREIRA VF 2010. $\beta$-Lapachona: Sua importância em química medicinal e modificações estruturais. Rev Virtual Quim 2: 140-160.

FIGURKA O, KHOMYAKA S, PLATONOVB M, MARTYNYUKB I, STADNICHUKB O, KOROLKOB S, LESKIVC H, YAREMKEVYCHA O AND NOVIKOVA V. 2015. Synthesis and biological evaluation of new amino 
derivatives of 1,4-naphthoquinone. J Chem Pharm Res 7: 912- 919.

FOREZI LSM, MARRA RKF, SILVA FC AND FERREIRA VF. 2017a. Synthetic Strategies for Obtaining Xanthenes. Curr Org Synth 14(7): 929-951.

FOREZI LSM, CARDOSO MFC, COSTA DCS, SILVA FC AND FERREIRA VF. 2017b. 2,3-Dichloro-1,4Naphthoquinone in Organic Synthesis: Recent Advances. Mini Rev Org Chem 14(5): 375-390.

FREIRE CPV, FERREIRA SB, OLIVEIRA NSM, MATSUURA ABJ, GAMA IL, SILVA FC, SOUZA MCBV, LIMA ES AND FERREIRA VF. 2010. Synthesis and biological evaluation of substituted $\alpha$ - and $\beta-2,3-$ dihydrofuran naphthoquinones as potent anticandidal agents. Med Chem Commun 1: 229-232.

FRYDMAN B ET AL. 1977. Induction of DNA Topoisomerase II-mediated DNA cleavage by $\beta$-Lapachone and related Naphthoquinones. Cancer Res 57: 620-627.

GAFNER S, WOLFENDER JL, NIANGA M, STOECKLIEVANS H AND HOSTETTMANN K. 1996. Antifungal and antibacterial naphthoquinones from Newbouldia laevis roots. Phytochemistry 42: 1315-1320.

GOODWIN TW AND MERCER EI. 1972. Introduction to plant Biochemistry. Oxford, New York: Pergamon Press.

GORDALIZA M. 2007. Natural products as leads to anticancer drugs. Clin Transl Oncol 9: 767-776.

GOTTLIEB OR. 1992. Biodiversidade: uma teoria molecular. Quim Nova 15: 167-172.

GOW NAR AND HUBE B. 2012. Importance of the Candida albicans cell wall during commensalism and infection. Curr Opin Microbiol 15: 406-412.

GWEE PS, KHOO KS, ONG HC AND SIT NW. 2014. Bioactivity-guided isolation and structural characterization of the antifungal compound, plumbagin, from Nepenthes gracilis. Pharm Biol 52: 1526-1531.

HASSAN STS, BERCHOVÁ-BÍMOVÁ K AND PETRÁŠ J. 2016. Plumbagin, a Plant-Derived Compound, Exhibits Antifungal Combinatory Effect with Amphotericin B against Candida albicans Clinical Isolates and Antihepatitis C Virus Activity. Phytother Res 30: 1487-1492.

HAZEN KC. 1998. Fungicidal versus fungistatic activity of terbinafine and itraconazole: an in vitro comparison. J Am Acad Dermatol 38: S37-41.

HOLMSTRÖM KM AND FINKEL T. 2014. Cellular mechanisms and physiological consequences of redoxdependent signaling. Nat Rev 15: 411-421.

HOOKER SC AND RICHARDSON AP. 1948. Naphthoquinone antimalarials. II. Correlation of structure and activity against P. lophurae in ducks. J Am Chem Soc 70: 3156-3165.

HUANG ST, KUO HS, HSIAO CL AND LIN YL. 2002. Efficient synthesis of 'redox-switched' naphthoquinone thiol-crown ethers and their biological activity evaluation. Bioorg Med Chem 10: 1947-1952.

HUESO-FALCÓNA I, AMESTY A, ANAISSI-AFONSO L, CASTRILLEJO IL, MACHÍN F AND ESTÉVEZBRAUN A. 2017. Synthesis and Biological Evaluation of Naphthoquinone-Coumarin Conjugates as Topoisomerase II Inhibitors. Bioorg Med Chem Lett 27: 484-489.

IBIS C, AYLA SS, BAHAR H, STASEVYCH MV, KOMAROVSKA-POROKHNYAVETS O AND NOVIKOV V. 2015. Synthesis, characterization and biological properties of novel piperidinol, piperidine and piperazine Substituted naphthoquinone compounds and their reactions with some thiols. Phosphorus Sulfur Silicon Relat Elem 190: 1422-1433.

IBIS C, OZSOY-GUNES Z, TUYUN AF, AYLA SS, BAHAR H, STASEVYCH MV, MUSYANOVYCH RY, KOMAROVSKA-POROKHNYAVETS O AND NOVIKOV V. 2016. Synthesis, antibacterial and antifungal evaluation of thio- or piperazinyl-substituted 1,4-naphthoquinone derivatives. J Sulfur Chem 37: 477 487.

IBIS C, TUYUN AF, BAHAR H, AYLA SS, STASEVYCH MV, MUSYANOVYCH RY, KOMAROVSKAPOROKHNYAVETS O AND NOVIKOV V. 2013b. Synthesis of novel 1,4-naphthoquinone derivatives: Antibacterial and antifungal agents. Med Chem Res 22: 2879-2888.

IBIS C, TUYUN AF, BAHAR H, AYLA SS, STASEVYCH MV, MUSYANOVYCH RY, KOMAROVSKAPOROKHNYAVETS O AND NOVIKOV V. 2014. Nucleophilic substitution reactions of 1,4-naphthoquinone and biologic properties of novel S-, S,S-, N-, and N,Ssubstituted 1,4-naphthoquinone derivatives. Med Chem Res 23: 2140-2149.

IBIS C, TUYUN AF, OZSOY-GUNES Z, AYLA SS, STASEVYCH MV, MUSYANOVYCH RY, KOMAROVSKA-POROKHNYAVETS O AND NOVIKOV V. 2013a. Synthesis and Antibacterial and Antifungal Properties of Novel S-, N-, N,S-, and S,OSubstituted 1,4-Naphthoquinone Derivatives. Phosphorus Sulfur Silicon Relat Elem 188: 955-966.

IBIS C, TUYUN AF, OZSOY-GUNES Z, BAHAR $\mathrm{H}$, STASEVYCH MV, MUSYANOVYCH RY, KOMAROVSKA-POROKHNYAVETS O AND NOVIKOV V. 2011. Synthesis and biological evaluation of novel sulfur-containing hetero-1,4-naphthoquinones as potent antifungal and antibacterial agents. Eur J Med Chem 46: 5861-5867.

INOUYE S, UCHIDA K, TAKIZAWA T, YAMAGUCHI H AND ABE S. 2006. Evaluation of the effect of terpenoid quinones on Trichophyton mentagrophytes by solution and vapor contact. J Infect Public Health 12: 100-104. 
IOSET JR, MARSTONA, GUPTAMPANDHOSTETTMANN K. 2000, Antifungal and larvicidal cordiaquinones from the roots of Cordia curassavica. Phytochemistry 53: 613617.

IZUMI E, UEDA-NAKAMURA T, DIAS FILHO BP, VEIGA JÚNIOR VF AND NAKAMURA CV. 2011. Natural products and Chagas disease: a review of plant compounds studied for activity against Trypanosoma cruzi. Nat Prod Rep 28: 809-823.

JARDOSH HH AND PATEL MP. 2013. Microwave-induced CAN promoted atom-economic synthesis of $1 \mathrm{H}-$ benzo[b] xanthene and $4 \mathrm{H}$-benzo[g]chromene derivatives of $\mathrm{N}$-allyl quinolone and their antimicrobial activity. Med Chem Res 22: 2954-2963.

JERNIGAN JA, PEARSON RD, PETRI WA AND ROGERS MD. 1996. In vitro activity of atovaquone against Leishmania chagasi promastigotes. Antimicrob Agents Chemother 40: 1064.

JORDÃO AK, VARGAS MD, PINTO AC, SILVA FC AND FERREIRA VF. 2015. Lawsone in organic synthesis. RSC Adv 5: 67909-67943

KARKARE S, CHUNG TTH, COLLIN F, LESLEY A. MITCHENALL LA, MCKAY AR, GREIVE SJ, MEYER JJM, LALL N AND MAXWELL A. 2013. The naphthoquinone diospyrin is an inhibitor of DNA gyrase with a novel mechanism of action. J Biol Chem 288: 51495156.

KASSAHUN K, PEARSON PG, TANG W, MCINTOSH I, LEUNG K, ELMORE C, DEAN D, WANG R, DOSS G AND BAILLIE TA. 2001. Studies on the metabolism of troglitazone to reactive intermediates in vitro and in vivo. Evidence for novel biotransformation pathways involving quinone methide formation and thiazolidinedione ring scission. Chem Res Toxicol 14: 62-70.

KAYSER O, KIDERLEN AF, LAATSCH H AND CROFT SL. 2000. In vitro leishmanicidal activity of monomeric and dimeric naphthoquinones. Acta Tropica 77: 307-314.

KENNEDY S, DICESARE JC AND SHEAFF RJ. 2011. Topoisomerase I/II inhibition by a novel naphthoquinone containing a modified anthracycline ring system. Biochem Biophys Res Commun 408: 94-98.

KHASIYATULLINA NR, V. MIRONOV VF, BOGDANOV AV, ZOBOV VV, VOLOSHINA AD, KULIK NV AND KONOVALOV AI. 2009. Synthesis and antibacterial and antifungal properties of some phosphorus-containing 1,2-dihydroxynaphthalenes. Pharm Chem J 43: 610-612.

KRISHNAN P AND BASTOW K F. 2000. Novel mechanisms of DNA topoisomerase II inhibition by pyranonaphthoquinone derivatives-eleutherin, alpha lapachone, and beta lapachone. Biochem Pharmacol 60: 1367-1379.

KUMAGAI Y, SHINKAI Y, MIURA T AND CHO AK. 2012. The Chemical Biology of Naphthoquinones and Its
Environmental Implications. Annu Rev Pharmacol Toxicol 52: 221-247.

KURYLOWICZ W. 1981 Antibióticos: Uma revisão Crítica. Edufpe: Recife, $341 \mathrm{p}$.

LEYVA E, LÓPEZ LI, GARCÍA DE LA CRUZ RF AND ESPINOSA-GONZÁLEZ CG. 2016. Synthesis and studies of the antifungal activity of 2-anilino-/2,3-dianilino-/2phenoxy- and 2,3-diphenoxy-1,4-naphthoquinones. Res Chem Intermed 43: 1813-1827.

LIFE - LEADING INTERNATIONAL FUNGAL EDUCATION. 2017a. http:/www.life-worldwide.org/ media-centre/article/the-burden-of-fungal-disease-newevidence-to-show-the-scale-of-the-problem. Accessed 20 September 2017.

LIFE - LEADING INTERNATIONAL FUNGAL EDUCATION. 2017b. http://www.life-worldwide.org/ fungal-diseases. Accessed 20 September 2017.

LIN AJ, COSBY LA, SHANSKY CW AND SARTORELLI AC. 1972. Potential Bioreductive Alkylating Agents. 1. Benzoquinone Derivatives. J Med Chem 15: 1247-1252.

LIN AJ, LILLIS BJ AND SARTORELLI AC. 1975. Potential bioreductive alkylating agents. 5. Antineoplastic activity of quinoline-5,8-diones, naphthazarins, and naphthoquinones. J Med Chem 18: 917-921.

LIN AJ, PARDINI RS, COSBY LA, LILLIS BJ, SHANSKY CW AND SARTORELLI AC. 1973. Potential bioreductive alkylating agents. 2. Antitumor effect and biochemical studies of naphthoquinone derivatives. J Med Chem 16: 1268-1271.

LIU KKC, LI J AND SAKYA S. 2004. Synthetic Approaches to the 2003 New Drugs. Mini Rev Med Chem 4: 11051125.

LOUVIS AR ET AL. 2016. Synthesis, characterization and biological activities of 3-aryl-1,4-naphthoquinones - green palladium-catalysed Suzuki cross couplings. New J Chem 40: 7643-7656.

LU C, YANG C AND XU Z. 2016. Three naphthoquinones from Streptomyces sp. XZYN-4. Rec Nat Prod 10: 430440.

LU JJ, BAO JL, WU GS, XU WS, HUANG MQ, CHEN XP AND WANG YT. 2013. Quinones Derived from Plant Secondary Metabolites as Anti-cancer Agents. Anticancer Agents Med Chem 13: 456-463.

MAHLER RH AND LORDES HE. 1971. Biological Chemistry, $2^{\text {nd }}$ ed., Herper International Edition: London.

MARTINS N, FERREIRA ICFR, BARROS L, SILVA S, HENRIQUES M. 2014. Candidiasis: Predisposing Factors, Prevention, Diagnosis and Alternative Treatment. Mycopathologia 177: 223-240.

MELO JG, SANTOS AG, AMORIM ELC, NASCIMENTO SC AND ALBUQUERQUE UP. 2011. Medicinal plants used as antitumor agents in Brazil: an ethnobotanical approach. Evid Based Complement Alternat Med: ID365359. 
MICKEVIČIENĖ K, BARANAUSKAITÉ R, KANTMINIENĖ K, STASEVYCH M, KOMAROVSKAPOROKHNYAVETS O AND NOVIKOV V. 2015. Synthesis and antimicrobial activity of N-substituted$\beta$-amino acid derivatives containing 2-hydroxyphenyl, benzo[b]phenoxazine and quinoxaline moieties. Molecules 20: 3170-3189.

MONTENEGRO RC ET AL. 2010 Cytotoxic activity of naphthoquinones with special emphasis on juglone and its 5-O-methyl derivative. Chem Biol Interact 184: 439-448.

MORTON RA. 1965. Biochemistry of Quinones. Academic Press: London, 585 p.

MURAKAMI K, HANEDA M, IWATA S AND YOSHINO N. 2010. Effect of hydroxy substituent on the prooxidant action of naphthoquinone compounds. Toxicol In Vitro 24: 905-909.

NAIRA SV, BARANWALA G, CHATTERJEEA M, ARUN SACHUC, VASUDEVANC AV, BOSEB C, BANERJIB A AND BISWASA R. 2016. Antimicrobial activity of plumbagin, a naturally occurring naphthoquinone from Plumbago rosea, against Staphylococcus aureus and Candida albicans. Int J Med Microbiol 306: 237-248.

NATURE MICROBIOLOGY. 2017. Editorial: Stop neglecting fungi. Nat Microbiol 2: 17120.

PADHYE S, DANDAWATE P, YUSUFI M, AHMAD A AND SARKAR FH. 2012. Perspectives on Medicinal Properties of Plumbagin and Its Analogs. Med Res Rev 32: 11311158.

PAIVA SR, FIGUEIREDO MR, ARAGÃO TV AND KAPLAN MA. 2003. Antimicrobial activity in vitro of plumbagin isolated from Plumbago species. Mem Inst Oswaldo Cruz 98: 959-961.

PAPPAS PG ET AL. 2016. Clinical Practice Guideline for the Management of Candidiasis: 2016 Update by the Infectious Diseases Society of America. Clin Infec Dis 62: e1-50

PATAI S. 1974. The chemistry of the quinoid compounds. J Wiley \& Sons: London.

PATAI S AND RAPPOPORT Z. 1988. The Chemistry of the Functional Groups. The Chemistry of the Quinonoid Compounds. J Wiley \& Sons: New York.

PAWAR AB, KILLEDAR AA, JADHAV KD AND SARAWADEKAR RG. 2012. X-ray diffraction, spectral and antimicrobial activity of bivalent metal ( $\mathrm{Zn}, \mathrm{Cd}, \mathrm{Hg}$, $\mathrm{Pb}$ and $\mathrm{Sn}$ ) chelates of 2-hydroxy 1,4-naphthoquinone. Int J Chemtech Res 4: 882-890.

PAWAR O, PATEKAR A, KHAN A, KATHAWATE L, HARAM S, MARKAD G, PURANIK V AND SALUNKE-GAWALI S. 2014 Molecular structures and biological evaluation of 2-chloro-3-(n-alkylamino)-1,4naphthoquinone derivatives as potent antifungal agents. $\mathrm{J}$ Mol Struct 1059: 68-74.
PAZ MM, ZHANG X, LU J AND HOLMGREN AA. 2012 New mechanism of action for the anticancer drug mitomycin C: mechanism-based inhibition of thioredoxin reductase. Chem Res Toxicol 25: 1502-1511.

PFALLER MA, DIEKEMA DJ, GIBBS DL, NEWELL VA, NAGY E, DOBIASOVA S, RINALDI M, BARTON R, VESELOV A AND THE GLOBAL ANTIFUNGAL SURVEILLANCE GROUP. 2008. Candida krusei, a Multidrug-Resistant Opportunistic Fungal Pathogen: Geographic and Temporal Trends from the Artemis Disk Antifungal Surveillance Program, 2001 to 2005. J Clin Microbiol 46: 515-521.

PHILLIPS RM, NAYLOR MA, JAFFAR M, DOUGHTY SW, EVERETT SA, BREEN AG, CHOUDRY GA AND STRATFORD IJ. 1999. Bioreductive activation of a series of indolequinones by human dt-diaphorase: structureactivity relationships. J Med Chem 42: 4071-4080.

PIANALTO KM AND ALSPAUGH JA. 2016. New Horizons in Antifungal Therapy. J Fungi 26: 1-24.

PINTO AV AND CASTRO SL. 2009. The trypanocidal activity of naphthoquinones: a review. Molecules 14: 4570-4590.

PINTO CN, DANTAS AP, DE MOURA KCG, EMERY FS, POLEQUEVITCH PF, PINTO MD, CASTRO SL AND PINTO AV. 2000. Chemical reactivity studies with naphthoquinones from Tabebuia with anti-trypanosomal efficacy. Arzneimittelforschung 50: 1120-1128.

PIYTA ZF, LI T, PAPAGEORGIOU VP, MELLIDIS AS, ASSIMOPOULOU AN, PITSINOS EM AND COULADOUROS EA. 1998. Inhibition of Topoisomerase I by naphthoquinone derivatives. Bioorg Med Chem Lett 8: 3385-3390.

RAO HSP, TANGETI VS AND ADIGOPILA LN. 2016. Synthesis and antimicrobial evaluation of 2-hydroxynaphthalene-1,4-dione and 4H-chromene conjugates. Res Chem Intermed 42: 7285-7303.

RASKIN I ET AL. 2002. Plants and human health in the twenty-first century. Trends Biotechnology 20: 522-531.

RĂU G, CREŢU FM, BERBECARU-IOVAN A, STĂNCIULESCU CE, ANDREI AM, MOGOŞANU GD, BĂLĂŞOIU M, BANIŢĂ IM AND PISOSCHI CG. 2016. Screening of thioalkanoic substituted 1,4-naphthoquinones as potent antimicrobial agents. Farmacia 64: 876-880.

ROEMER T AND KRYSAN DJ. 2014. Antifungal Drug Development: Challenges, Unmet Clinical Needs, and New Approaches. Cold Spring Harb Perspect Med 4: a019703.

RUTKAUSKAS K, MICKEVIČIUS V, KANTMINIENĖ K, STASEVYCH M, KOMAROVSKA-POROKHNYAVETS O, MUSYANOVYCH R AND NOVIKOV V. 2013. Synthesis and antimicrobial activity of 1,3-disubstituted pyrrolidinones with hydrazone and naphthoquinone moieties. Chemija 24: 74-80. 
RYU CK, SHIM JY, CHAE MJ, CHOI IH, HAN JY, JUNG OJ, LEE JY AND JEONG SH. 2005. Synthesis and antifungal activity of 2/3-arylthio- and 2,3-bis(arylthio)-5-hydroxy15-methoxy-1,4-naphthoquinones. Eur J Med Chem 40: 438-444.

RYU CK AND CHAE MJ. 2005. Synthesis and antifungal activity of naphthalene-1,4-diones modified at positions 2, 3, and 5. Arch Pharm Res 28: 750- 755.

SALAS CO, FAÚNDEZ M, MORELLO A, MAYA JD AND TAPIA RA. 2011. Natural and synthetic naphthoquinones active against Trypanosoma cruzi: an initial step towards new drugs for Chagas disease. Curr Med Chem 18: 144161.

SÁNCHEZ-CALVO JM, BARBERO GR, GUERREROVÁSQUEZ G, DURÁN AG, MACÍAS M, RODRÍGUEZIGLESIAS MA, MOLINILLO JMG AND MACÍAS FA. 2016. Synthesis, antibacterial and antifungal activities of naphthoquinone derivatives: a structure-activity relationship study. Med. Chem. Res 25: 1274-1285.

SANGLARD D. 2016. Emerging Threats in AntifungalResistant Fungal Pathogens. Front Med 3: 11.

SANTOS D, SANTOS MMM, VIANA RJS, CASTRO RE, MOREIRA R AND RODRIGUES CMP. 2009. Naphtho[2,3-d]isoxazole-4,9-dione-3-carboxylates: Potent, non-cytotoxic, antiapoptotic agentes. Chem Biol Interact 180: 175-182.

SANTOS EVM DOS, CARNEIRO JWM AND FERREIRA VF. 2004. Quantitative structure-activity relationship in aziridinyl-1,4-naphthoquinone antimalarials: study of theoretical correlations by the PM3 method. Bioorg Med Chem 12: 87-93.

SANTOS MMM, FARIA N, ILEY J, COLES SJ, HURSTHOUSE MB, MARTINS ML AND MOREIRA R. 2010. Reaction of naphthoquinones with substituted nitromethanes. Facile synthesis and antifungal activity of naphtho[2,3-d]isoxazole-4,9-diones. Bioorg Med Chem Lett 20: 193-195.

SASAKI K, ABE H AND YOSHIZAKI F. 2002. In vitro antifungal activity of naphthoquinone derivatives. Biol Pharm Bull 25: 669-670.

SCORZONI L, DE PAULA E SILVA ACA, MARCOS CM, ASSATO PA, DE MELO WCMA, DE OLIVEIRA HC, COSTA-ORLANDI CB, MENDES-GIANNINI MJS AND FUSCO-ALMEIDA AM. 2017. Antifungal Therapy: New Advances in the Understanding and Treatment of Mycosis. Front Microbiol 8: 36.

SHARMA U, KATOCH D, SOOD S, KUMAR N, SINGH B, THAKUR A AND GULATI A. 2013. Synthesis, antibacterial and antifungal activity of 2-amino-1,4naphthoquinones using silica-supported perchloric acid (HClO4-SiO2) as a mild, recyclable and highly efficient heterogeneous catalyst. Indian J Chem 52B: 1431-1440.
SHINDE PV AND WADEKAR MP. 2015. Structural, thermal and antifungal activity studies of isomeric Sm(III) juglonates. Der Pharma Chem 7: 231-239.

SHRESTHA JP, BAKER C, KAWASAKI Y, SUBEDI Y, PAUL NNV, TAKEMOTO JU AND CHANG CWT. 2017. Synthesis and bioactivity investigation of quinone-based dimeric cationic triazolium amphiphiles selective against resistant fungal and bacterial pathogens. Eur J Med Chem 126: 696-704.

SIDJUI SL, ZEUKO'O EM, TOGHUEO RMK, NOTÉ OP, MAHIOU-LEDDET V, HERBETTE G, FEKAM FB, OLLIVIER E AND FOLEFOC GN. 2014. Secondary metabolites from Jacaranda mimosifolia and Kigelia Africana (Bignoniaceae) and their anticandidal activity. Rec Nat Prod 8: 307-311.

SILVA FC AND FERREIRA VF. 2016. Natural Naphthoquinones with Great Importance in Medicinal Chemistry. Curr Org Synth 13: 334-371.

SILVA JUNIOR EM ET AL. 2008. Synthesis and antiTrypanosoma cruzi activity of derivatives from norlapachones and lapachones. Bioorg Med Chem 16: 50305038.

SILVA TL, FERREIRA FR, VASCONCELOS CC, LIMA DJP, COSTA PRR, NETTO CD AND GOULART MOF. 2016. Reactive oxygen species release, alkylating ability, and DNA interactions of a pterocarpanquinone: A test case for electrochemistry. ChemElectroChem 3: 1-13.

SKIBO EB, XING C AND DORR RT. 2001. Aziridinyl Quinone Antitumor Agents Based on Indoles and Cyclopent $[b]$ indoles: Structure-Activity Relationships for Cytotoxicity and Antitumor Activity. J Med Chem 44: 3545-3562.

SOEJARTO DD AND FARNSWORTH NR. 1989. The value of plants used in traditional medicine for drug discovery. Perspect Biol Med 32: 244-256.

SREELATHA T, KANDHASAMY S, DINESH R, SHRUTHY S, SHWETA S, MUKESH D, KARUNAGARAN D, BALAJI R, MATHIVANAN N AND PERUMAL PT. 2014. Synthesis and SAR study of novel anticancer and antimicrobial naphthoquinone amide derivatives. Bioorg Med Chem Lett 24: 3647-3651.

SRITRAIRAT N ET AL. 2011. Antifungal activity of lawsone methyl ether in comparison with chlorhexidine. J Oral Pathol Med 40: 90-96.

STAGLIANO KW ET AL. 2006. Regiocontrolled synthesis and HIV inhibitory activity of unsymmetrical binaphthoquinone and trimeric naphthoquinone derivatives of conocurvone. Bioorg Med Chem 14: 5651-5665.

TAN G, GYLLENHAAL C AND SOEJARTO DD. 2006. Biodiversity as a Source of Anticancer Drugs. Curr Drug Targets 7: 265-277.

TANAKA H, MARUMO H, NAGAI T, OKADA M, TANIGUCHI K AND OMURA S. 1975. Nanaomycins, 
new antibiotics produced by a strain of Streptomyces III. A new component, nanaomycin c, and biological activities of nanaomycin derivatives. J Antibiotic 28: 868-875.

TANDON VK, CHHOR RB, SINGH RV, RAI S AND YADAVA DB. 2004a. Design, synthesis and evaluation of novel 1,4-naphthoquinone derivatives as antifungal and anticancer agents. Bioorg Med Chem Lett 14: 1079- 1083.

TANDON VK, MAURYA HK, MISHRA NN AND SHUKLA PK. 2009b. Design, synthesis and biological evaluation of novel nitrogen and sulfur containing hetero-1,4naphthoquinones as potent antifungal and antibacterial agents. Eur J Med Chem 44: 3130- 3137.

TANDON VK, MAURYA HK, MISHRA NN AND SHUKLA PK. 2011. Micelles catalyzed chemoselective synthesis in water' and biological evaluation of oxygen containing hetero-1,4-naphthoquinones as potential antifungal agents. Bioorg Med Chem Lett 21: 6398-6403.

TANDON VK, MAURYA HK, TRIPATHI A, SHIVAKESHAVA GB, SHUKLA PK, SRIVASTAVA P AND PANDA D. 2009a. 2,3-Disubstituted-1,4naphthoquinones, 12H-benzo[b]phenothiazine-6,11diones and related compounds: Synthesis and Biological evaluation as potential antiproliferative and antifungal agents. Eur J Med Chem 44: 1086-1092.

TANDON VK, MAURYA HK, VERMA MK, KUMAR R AND SHUKLA PK. 2010. 'On water' assisted synthesis and biological evaluation of nitrogen and sulfur containing hetero-1,4-naphthoquinones as potent antifungal and antibacterial agents. Eur J Med Chem 45: 2418-2426.

TANDON VK, SINGHB RV AND YADAVA DB. $2004 \mathrm{~b}$. Synthesis and evaluation of novel 1,4-naphthoquinone derivatives as antiviral, antifungal and anticancer agents. Bioorg Med Chem Lett 14: 2901-2904.

TANDON VK, YADAV DB, CHATURVEDIB AK AND SHUKLAB PK. 2005b. Synthesis of (1,4)-naphthoquinono[3,2-c]-1H-pyrazoles and their $(1,4)$-naphthohydroquinone derivatives as antifungal, antibacterial, and anticancer agents. Bioorg Med Chem Lett 15: 3288-3291.

TANDON VK, YADAV DB, MAURYA HK, CHATURVEDI AK AND SHUKLA PK. 2006. Design, synthesis, and biological evaluation of 1,2,3-trisubstituted-1,4dihydrobenzo[g]quinoxaline-5,10-diones and related compounds as antifungal and antibacterial agents. Bioorg Med Chem 14: 6120-6126.

TANDON VK, YADAV DB, SINGH RV, CHATURVEDIC AK AND SHUKLA PK. 2005a. Synthesis and biological evaluation of novel (L)-a-amino acid methyl ester, heteroalkyl, and aryl substituted 1,4-naphthoquinone derivatives as antifungal and antibacterial agents. Bioorg Med Chem Lett 15: 5324-5328.

TEIXEIRA MJ, DE ALMEIDA YM, VIANA JR, HOLANDA JG, RODRIGUES TP, PRATA JRC, COELHO IVB, RAO VS AND POMPEU MML. 2001. In vitro and in vivo Leishmanicidal activity of 2-hydroxy-3-(3-methyl2-butenyl)-1,4-naphthoquinone (lapachol). Phytother Res 15: 44-48.

THOMPSON RH. 1997. Naturally Occuring Quinones IV: Recents Advances. $4^{\text {th }}$ ed., Londres: Champman \& Hall, $746 \mathrm{p}$.

THOMSON RH. 1997. Naturally Occurring Quinones IV, Blackie Academic \& Professional: London.

TOTEVA MM AND RICHARD JP. 2011. The generation and reactions of quinone methides. Adv Phys Org Chem 45: 63-67.

TRAN NC, LE MT, NGUYEN DN AND TRAN TD. 2009. Synthesis and biological evaluation of halogen-substituted 1,4-naphthoquinones as potent antifungal agents. International Electronic Conference on Synthetic Organic Chemistry, 13th, Nov. 1-30, tran1/1-tran1/7.

TUYUN AF, BAYRAK N, YILDIRIM H, ONUL N, KARA EM AND CELIK BO. 2015. Synthesis and in vitro biological evaluation of aminonaphthoquinones and Benzo[b]phenazine-6,11-dione derivatives as potential antibacterial and antifungal compounds. J Chem Article ID 645902: 1-9.

VAICKELIONIENĖ R, VYTAUTAS MICKEVIČIUS V, MIKULSKIENE G, STASEVYCH M, KOMAROVSKAPOROKHNYAVETS O AND NOVIKOV V. 2011. Reactions of 5-oxo-1-phenylpyrrolidine-3carbohydrazides with 1,4-naphthoquinone derivatives and the properties of the obtained products. Res Chem Intermed 37: 1009-1027.

VITAKU E AND NJARDARSON JT. 2013. An in-pharmative educational poster anthology highlighting the therapeutic agents that chronicle our medicinal history. J Chem Educ 90: 1403-1405.

VOSKIENĖ A, SAPIJANSKAITĖ B, MICKEVIČIUS V, JONUŠKIENĖ I, STASEVYCH M, KOMAROVSKAPOROKHNYAVETS O, MUSYANOVYCH R AND NOVIKOV V. 2012. Synthesis and microbiological evaluation of new 2- and 2,3-diphenoxy-substituted naphthalene-1,4-diones with 5-oxopyrrolidine moieties. Molecules 17: 14434-14448.

VOSKIENĖ A, SAPIJANSKAITE் B, MICKEVIČIUS V, KANTMINIENE் K, STASEVYCH M, KOMAROVSKAPOROKHNYAVETS O, MUSYANOVYCH R AND NOVIKOV V. 2011. Synthesis, chemical properties, and antimicrobial activity of 2- and 2,3-substituted [(tetrahydro-2,4-dioxopyrimidin-1(2H)-yl)phenoxy] naphthalene-1,4-diones. Monatsh Chem 142: 529-537.

WELLINGTON KW. 2015. Understanding cancer and the anticancer activities of naphthoquinones - a review. RSC Adv 5: 20309-20338.

WHITTEMORE R AND KNAFL K. 2005. The integrative review: updated methodology. J Adv Nurs 52: 546-553. 
WHO - WORLD HEALTH ORGANIZATION. 2016. World cancer statistics for 2012. http:/Www.who.int/cancer/en/.

WILHANSON J AND SCOTT-FINNINGAN TJ. 1981. Trypanocidal activity of daunorubicin and related compounds. Nature 292: 466-467.

WISPLINGHOFF H, BISCHOFF T, TALLENT SM, SEIFERT H, WENZEL RP AND EDMOND MB. 2004. Nosocomial bloodstream infections in US hospitals: analysis of 24,179 cases from a prospective nationwide surveillance study. Clin Infect Dis 39: 309-317.

WITTEBOLLE V, LEMRISS S, MORELLA GL, ERRANTE J, BOIRON P, BARRET R AND SARCIRON ME. 2006. Antifungal effects of aminosulphoxide and disulphide derivatives. Mycoses 49: 169-175.
YAMASHITA M, KANEKO M, TOKUDA H, NISHIMURA K, KUMEDA Y AND IIDA A. 2009. Synthesis and evaluation of bioactive naphthoquinones from the Brazilian medicinal plant, Tabebuia avellanedae. Bioorg Med Chem 17: 6286-6291.

YILDIRIM H, BAYRAK N, TUYUN AF, KARA EM, ÇELIK BO AND GUPTA GK. 2017. 2,3-Disubstituted1,4-naphthoquinones containing an arylamine with trifluoromethyl group: synthesis, biological evaluation, and computational study. RSC Adv 7: 25753-25764.

ZHANG Y, LI XM, WANG CY AND WANG BG. 2007. A new naphthoquinoneimine derivative from the marine algal-derived endophytic fungus Aspergillus niger EN-13. Chin Chem Lett 18: 951-953. 